\title{
THE ROLE AND IMPACT OF THE EU'S COMMON FOREIGN AND SECURITY POLICY TOWARDS THE WESTERN BALKANS (2001-2006)
}

\begin{abstract}
Steven Blockmans*
Summary: In the period from 2001 to 2006, the Western Balkans served as a testing ground for the development of the EU's Common Foreign and Security Policy. This paper explores a variety of legal and political aspects of the EU's efforts to stabilise the Western Balkans in an attempt to answer the question about what the EU should have learned in so doing. Attention is paid to the diplomatic efforts of the $E U$ to prevent (the escalation of) conflict in Macedonia, between Serbia and Montenegro, and in Kosovo. The role and impact of the EU's first-ever - and so far biggest - police and military operations are also evaluated. It is argued that lessons learned from these actions should be taken to heart before the EU decides to embark on any future missions. Otherwise, history may prove that the Western Balkans offered the EU's one and only chance to develop credible and lasting foreign policy, security, and defence arrangements.
\end{abstract}

\section{The gradual development of CFSP/ESDP}

Since the entry into force of the Treaty of Maastricht, the Member States of the European Union have actively used the diplomatic structures with which they had endowed "their" Common Foreign and Security Policy (CFSP). Since the entry into force of the Treaty of Amsterdam, Javier Solana, Secretary General/High Representative for the CFSP (SG/HR), supported by his staff at the Council, has made the most of the cautious wording of his tasks in Article 26 TEU. In the Western Balkans, the European Union, by way of its SG/HR, was instrumental in brokering a peace deal between the government and the Albanian separatists in Macedonia (2001) and in hammering out the Belgrade Agreement (2002) to prevent the Federal Republic of Yugoslavia (FRY) from falling apart and having a knock-on effect on the precarious balance reached in Kosovo. ${ }^{1}$ The question remains, however, whether these and other diplomatic constructs can sustain the disintegrative forces still at work in parts of the Western

\footnotetext{
"Senior research fellow in EU Law, T.M.C. Asser Institute, The Hague.

${ }^{1}$ The term "Macedonia" is used here as an informal name. Greece believes that the name Macedonia should properly be applied to its own northern region with origins dating from the time of Alexander the Great. Similarly, the name "Kosovo" is used here in spite of the Albanian and Serb appellations for the region, respectively "Kosova" and "Kosovo-Metohija".
} 
Balkans. With the peaceful separation of Serbia and Montenegro in June 2006 and the negotiations on the final status of Kosovo well underway, the answer to this question is highly relevant for the EU's ongoing efforts to stabilise the Western Balkans.

History has shown that rogue leaders with bad intentions only understand the language of diplomacy backed by force. ${ }^{2}$ For long it has been clear that the EU is in need of other, more persuasive machinery to force parties (that have the intention of) fighting each other in an armed conflict not to commit heinous crimes such as ethnic cleansing and religious persecution, and to settle their differences in a peaceful manner. The need to move beyond the paper security structures which were introduced in the Treaty on European Union during the 1991 IGC quickly became apparent with the violent disintegration of the Socialist Federal Republic of Yugoslavia (SFRY) at the end of that year and the ensuing war in Bosnia-Herzegovina (1992-1995). In the absence of its own security and defence capabilities, the European Union could avail itself of the Western European Union (WEU) to elaborate and implement decisions and actions of the Council which had "defence" implications. ${ }^{3}$ The word "defence" was to be interpreted in the broad sense, since it explicitly did not include a common defence of the territory of the EU. The term referred to military cooperation in actions "out-of-area". Reviewing the significant changes that had taken place in the security situation in Europe after the outbreak of the Yugoslav crisis, the WEU Council of Ministers, at its 19 June 1992 meeting in Petersberg (near Bonn), redefined its operational role so as to include the deployment of military units of WEU Member States for "humanitarian and rescue tasks, peacekeeping tasks and tasks of combat forces in crisis management, including peacemaking" to implement conflict prevention or crisis management measures taken within the framework of the OSCE or the UN. ${ }^{4}$ While military units

\footnotetext{
${ }^{2}$ See, eg, R Holbrooke, To End a War (Random House, New York 1998) 146.

${ }^{3}$ Treaty on European Union (Maastricht Treaty) [in subsequent footnotes TEU] art J.4(2). See also Council document on the Relations between the Union and the WEU, EU Bull 10-1993 adopted by the Council of the EU on 26 October 1993 and accepted by the WEU Council of Ministers on 22 November 1993, and as Document 1412 of the Assembly of the WEU, 8 April 1994. For more details on the legal relationship between the two international organisations, see R Wessel, 'The EU as a Black Widow: Devouring the WEU to Give Birth to a European Security and Defence Policy' in V Kronenberger (ed), The European Union and the International Legal Order: Discord or Harmony? (T.M.C. Asser Press, The Hague 2001) 405-434.

4 The WEU Declaration of 19 June 1992 is reproduced in C Hill and K Smith, European Foreign Policy: Key Documents (Routledge, London 2000) 205-211. On the question whether the WEU, in extending its original collective defence task to completely new functions, was acting ultra vires, see R Wessel, 'The Legality of the New Functions of the Western European Union: The Attribution of Powers Reconsidered on the Occasion of the $50^{\text {th }}$ Anniversary of the Brussels Treaty' in A Deighton and E Remacle (eds), The Western European Union, 1948-1998: From the Brussels Treaty to the Treaty of Amsterdam (1-2 Studia Diplomatica, 1998) 15-28.
} 
of the ten WEU Member States, all also EU Member States, conducted operations in the Adriatic ${ }^{5}$ and on the Danube, ${ }^{6}$ they did not do so in support of decisions taken by the European Union. The only request of the EU in the first half of the nineties to make use of WEU capabilities in the Western Balkans concerned the support for the EU administration of the Bosnian town of Mostar (1994). ${ }^{7}$ Unfortunately, this operation was generally perceived a failure, especially by the parties to the conflict. ${ }^{8}$ With the crises in Albania (1997) and Kosovo (1999), the European Union was further embarrassed at how little it could contribute to the prevention and/or "management" of conflicts at its doorstep. Reliance upon US diplomacy and NATO's military strength condemned the Union to paying the bills, while not moving the emphasis to short-term conflict prevention and crisis management.

Frustration at such inadequacies and calls for change by others, notably the US, led France and the United Kingdom, the EU Member States that pack most military punch, to prod their colleagues at the European Council's December 1999 summit at Helsinki in carrying forward work on the development of the Union's own military (and non-military) crisis management capability with the objective of a strengthened and credible European policy on security and defence. ${ }^{9}$ At its meeting in Helsinki the

\footnotetext{
${ }^{5}$ See <http://www.weu.int>. In July 1992, the WEU Ministerial Council decided that WEU naval forces would participate in monitoring the UN embargo against former Yugoslavia in the Adriatic. NATO was also conducting its own operation at the time. On 8 June 1993, the WEU and NATO Councils met to approve a combined concept for "Operation Sharp Guard" in support of UN Security Council Resolution 820 (1993).

${ }^{6}$ Ibid Following an extraordinary meeting of the WEU Council of Ministers in Luxembourg on 5 April 1993, it was agreed that WEU Member States would provide assistance to Bulgaria, Hungary and Romania in their efforts to enforce the UN sanctions on the Danube. In June 1993, the three riparian states accepted this offer and agreed with WEU on the setting-up of a police and customs operation.

7 Ibid The request of the Council was not presented in an official decision. The cooperation was not based on TEU art J.4(2) since no defence issues were involved. See J-F Paganon, 'Western European Union's Pivotal Position Between the Atlantic Alliance and the European Union' in A Deighton (ed), Western European Union 1954-1997: Defence, Security, Integration (European Independent research Unit, Oxford 1997) 93-102, at 97. Three later requests of the EU for WEU support pursuant to TEU art J.4(2) concerned: the clearance of landmines in Croatia; the general security surveillance of the Kosovo region; and the provision of advice to and training instructors of the Albanian police. For more on each of these operations, see S Blockmans, Tough Love: the European Union's Relations with the Western Balkans (T.M.C. Asser Press, The Hague 2007) forthcoming.

${ }^{8}$ For critical assessments of the EU's performance in Mostar, see eg S Orucevi , 'Mostar: Europe's Failure' (1996) 15 Bosnia Report and S Markotich, 'Pursuing Balkan Peace' (1996) 30 OMRI Special Report.

${ }^{9}$ As a result of a meeting between French President Jacques Chirac and British Prime Minister Tony Blair at Saint-Malo, a joint Franco-British declaration on European defence was issued on 4 December 1998, stating that "[t]he Union must have the capacity for autonomous action, backed up by credible military forces, the means to decide to use them and a readiness to do so, in order to respond to international crises." The joint declaration
} 
European Council underlined its determination to develop an autonomous capacity to take decisions and, where NATO as a whole was not engaged, to launch and conduct EU-led military operations in response to international crises. ${ }^{10}$ To this end, the European Council agreed that:

by the year 2003, cooperating together voluntarily, [Member States] will be able to deploy rapidly and then sustain forces capable of the full range of Petersberg tasks as set out in the Amsterdam Treaty, including the most demanding, in operations up to corps level (up to 15 brigades or 50,000-60,000 persons). These forces should be militarily self-sustaining with the necessary command, control and intelligence capabilities, logistics, other combat support services and additionally, as appropriate, air and naval elements. Member States should be able to deploy in full at this level within 60 days, and within this to provide smaller rapid response elements available and deployable at very high readiness. They must be able to sustain such a deployment for at least one year. This will require an additional pool of deployable units (and supporting elements) at lower readiness to provide replacements for the initial forces. ${ }^{11}$

This so-called "common European headline goal" represented a political commitment by the Member States to develop a Rapid Reaction Force and to progressively improve the Union's military capabilities for crisis management operations. In subsequent steps, the European Council agreed to the institution of new political and military bodies, structures, and procedures to be established within the Council to ensure political guidance and strategic direction; ${ }^{12}$ the principles for consultation and cooperation with non-European allies and NATO in crisis management; ${ }^{13}$ measures to enhance the Union's civilian capabilities in the

is reproduced in C Hill and K Smith, European Foreign Policy: Key Documents (Routledge, London 2000) 243-244.

10 The WEU Council facilitated this ambition by the EU by deciding "to prepare the WEU legacy and the inclusion of those functions of the WEU, which will be deemed necessary by the EU to fulfil its new responsibilities in the area of crisis-management tasks." See WEU Ministerial Council, Luxembourg Declaration, 23 November 1999, para 4.

${ }^{11}$ EU Bull 12-1999, Annexes to the Presidency Conclusions, Annex 1 to Annex IV.

12 Following up on an agreement reached by the defence ministers of the EU at their informal meeting at Sintra on 28 February 2000, the interim structures that prepared the Political and Security Committee, EU Military Committee, and EU Military Staff, started their activities in Brussels on 1 March 2000. See EU Bull 3-2000 point I-20. In December 2000, the Council decided to make the interim committees permanent in the year 2001. See EU Bull 12-2000 point I.6. The process to enhance European capabilities has recently been given a fresh impetus with the creation of the European Defence Agency. See Council Joint Action (CFSP) 2004/551/ on the establishment of the European Defence Agency [2004] OJ L 245/17. See A Ambos, 'The Institutionalisation of CFSP and ESDP', in D Mahncke, A Ambos and C Reynolds (eds), European Foreign Policy: From Rhetoric to Reality? (Peter Lang, Brussels 2004) 165-192.

13 On the so-called "Berlin Plus" Agreement of 16 December 2002, which allows the EU to draw on some of NATO's military assets in its own peacekeeping operations, see chapter 
area of crisis management; ${ }^{14}$ the European Security Strategy (ESS), the first comprehensive approach to security issues; ${ }^{15}$ measures to enhance EU military capabilities (the new Headline Goal 2010); and a timetable for carrying forward work on all of these issues. ${ }^{16}$

Thus, in a very short timeframe, the European Union disentangled itself from the $\mathrm{WEU}^{17}$ and developed what was needed to create an ability of its own to undertake the full range of Petersberg tasks. ${ }^{18}$ These developments found their way into the Treaty of Nice of December 2000. ${ }^{19}$

3.2.1 below and M Reichard, 'Some Legal Issues Concerning the EU-NATO Berlin Plus Agreement' (2004) 73 Nordic JIL 37-67. More generally, see M Reichard, A Shifting Balance: Legal and Political Aspects of the EU-NATO Relationship (Ashgate, Aldershot 2006).

14 The June 2000 Feira European Council decided to set up a European Security and Intelligence Force (ESIF) which, in time, is to consist of 5,000 well-armed police, 1,000 of them to be deployable within 30 days, able to carry out preventive as well as repressive actions in support of global peacekeeping missions. See EU Bull 6-2000, point I.8.11. Further, see Council Decision (CFSP) 2000/354/ setting up a Committee for civilian aspects of crisis management [2000] OJ L 127/1; and Council Conclusions on the Civilian Headline Goal 2008 Press release 14960/05 (Presse 317) 12 December 2005.

${ }^{15}$ EU Bull 12-2003, point I.32.83. The ESS, on page 8, includes the following reference to the Western Balkans when listing strategic objectives for the Union: "Our task is to promote a ring of well governed countries to the East of the European Union and on the borders of the Mediterranean with whom we can enjoy close and cooperative relations. The importance of this is best illustrated in the Balkans. Through our concerted efforts with the US, Russia, NATO and other international partners, the stability of the region is no longer threatened by the outbreak of major conflict. The credibility of our foreign policy depends on the consolidation of our achievements there. The European perspective offers both a strategic objective and an incentive for reform." On the ESS, see eg R Kissack, 'The European Security Strategy: A First Appraisal' (2004) 2 CFSP Forum,19-20; and S Duke, The European Security Strategy in a Comparative Framework: Does it Make for Secure Alliances in a Better World?',(2004) 9 EFA Rev,459-481.

${ }^{16}$ For an overview of the Union's efforts to build an ESDP, see eg S Blockmans 'A New Crisis Manager at the Horizon - The Case of the European Union' (2000) 13 LJIL 255-263; S Duke, The EU and Crisis Management: Development and Prospects (EIPA, Maastricht 2001); A Deighton, 'The European Security and Defence Policy',(2002) 40 JCMS 719-741; H Neuhold and E Sucharipa (eds), The CFSP/ESDP After enlargement: A Bigger EU = A Stronger EU? (Favorita Papers, Vienna School of International Studies 2003); N. Gnesotto (ed.), EU Security and Defence Policy: The First Five Years (1999-2004) (Paris, EUISS 2004); S Biscop, 'Able and Willing? Assessing the EU's Capacity for Military Action' (2004) 9 EFA Rev 509-527; and S Biscop (ed), E Pluribus Unum? Military Integration in the European Union (Academia Press, Brussels 2005).

17 With the 13 November 2000 Marseille Declaration of the WEU Council, the transfer of some WEU institutions (the Satellite Centre and the EUISS) was decided upon and the routine consultation mechanisms between WEU and EU and WEU and NATO were suspended. The EU agreed to take over the WEU institutions as well as the WEU activities which were still running (MAPE; the De-mining Assistance Mission to the Republic of Croatia was continued under the responsibility of Sweden until 9 May 2001, when its mandate expired). The WEU thus returned to the organisation that was originally set up to deal with collective defence matters in 1948: the Brussels Treaty Organisation. See R Wessel, (n 2).

18 The content of which had already to a great extent been codified in TEU art 17(2) by the Treaty of Amsterdam.

${ }^{19}$ In TEU art 17, as amended, all references to the WEU were deleted. See R Wessel, 'The State of Affairs in European Security and Defence Policy: The Breakthrough in the Treaty of Nice' (2003) 8 Journal of Conflict \& Security Law 265-288. 
The European Security and Defence Policy (ESDP) was - somewhat prematurely - declared operational at the European Council of Laeken on 14 and 15 December 2001. ${ }^{20}$ The most striking manifestation - and raison d'être - of this policy is the Union's capacity to back its diplomatic efforts by action on the ground, i.e. its crisis management operations. Since 2001, the European Union has affirmed its operational capability through the launching of seventeen ESDP operations, five of which, so nearly one third of all missions, took or are still taking place in the Western Balkans: EU Police Mission (since 2003) and EUFOR Althea (since 2004) in Bosnia-Herzegovina, Concordia (2003), Proxima (2003-2005) and EUPAT (since 2005) in Macedonia. ${ }^{21}$

This paper explores a variety of legal and political aspects of the European Union's Common Foreign and Security Policy towards the Western Balkans in the period from 2001 to 2006. Attention is paid to the diplomatic efforts of the EU to prevent or suppress violent conflicts in Macedonia, between Serbia and Montenegro, and in Kosovo (section 2). Subsequently, the role and impact of the five ESDP operations that have been launched in the Western Balkans since 2001 are examined (section 3). Some conclusions on the role and impact of the EU's CFSP in the Western Balkans will be drawn at the end (section 4). This paper is not concerned with ESDP operations avant la lettre, ${ }^{22}$ nor will it deal with the institutional changes of the Union's CFSP and ESDP as a result of the conflicts in the Western Balkans. ${ }^{23}$

\footnotetext{
${ }^{20}$ EU Bull 12-2001, points I.5.6 and I.28. The Thessaloniki European Council of 19 and 20 June 2003 admitted recognised shortfalls in the Union's operational capability across the full range of Petersberg tasks, but considered that they could be alleviated by the further development of the EU's military capabilities. See EU Bull 6-2003, point I.23.56.

${ }^{21}$ For an up-to-date list of ESDP operations see <http://ue.eu.int/cms3_fo/showPage. asp?id=268\&lang $=\mathrm{EN} \& \operatorname{mode}=\mathrm{g}>$.

${ }^{22}$ See (n 7).

${ }^{23}$ See, ,S Duke, 'From Amsterdam to Kosovo: Lessons for the Future of CFSP' (1999) 2 Eipascope 2-15; C Piana, 'The EU's Decision-making Process in the Common Foreign and Security Policy: The Case of the Former Yugoslav Republic of Macedonia' (2002) 7 EFA Rev 209-226; and P Latawski and M Smith, The Kosovo Crisis and the Evolution of post-Cold War European Security (Manchester University Press, Manchester 2003) in particular 120-142.
} 


\section{Diplomatic endeavours}

\subsection{Coupe macédoine $e^{24}$}

\subsubsection{Protecting minority rights ${ }^{25}$}

In 2001, a conflict erupted between Albanian and Slavic Macedonians which brought the country on the brink of an outright civil war. Macedonia had never really succeeded to integrate its Albanian citizens. The Albanian Macedonians boycotted the 1991 referendum on independence from the SFRY and the attendant census because the Macedonian Constitution did not recognise them as a constituent nation of Macedonia. ${ }^{26}$ In January 1992 they held a plebiscite of their own in which they opted for autonomy. They publicly and recurrently rejected the results of the 1994 internationally monitored census (according to which Albanians made up 23 per cent of the population, amended by a later census to 26 per cent). Many Albanians in Western Macedonia felt closer to their kith and kin in Kosovo than to the Macedonian state. Albanians occasionally accused the Slavic Macedonians of discrimination in the labour market, in secondary, and higher education, in expenditures on infrastructure (many Albanian villages still lack proper roads and are not connected to the national water and electricity grids), and in the public administration. Albanians claimed that police brutality, discriminatory legislation, and the exclusive use of the Macedonian language violated their human and civil rights. Gradually, they lost faith in the Slavic Macedonians' will to accommodate their demands, however legitimate. To this, the Macedonians would retort that Albanians made up a hefty chunk of the informal economy, thus distorting official unemployment figures; that Albanians in Western Macedonia largely did not pay taxes; that their under-representation in state administration was due to the lack of properly qualified and educated people; and that infrastructure all over the country was decrepit. Macedonians intermittently accused the Albanians of illegal construction, purchases of real estate at inflated prices, mass immigration from Kosovo, re-population of Macedonian villages abandoned by their inhabitants, ethnic cleansing by intimidation of urban neighbourhoods,

\footnotetext{
${ }^{24}$ A dessert of a blended combination of fresh fruit. For analyses on the history of Macedonia since the break-up of Yugoslavia, see J Pettifer (ed), The New Macedonian Question (Palgrave, Basingstoke 2001).

${ }_{25}$ The facts described in this section are primarily based on the Balkan Crisis Reports of the London-based Institute for War \& Peace Reporting <http://www.iwpr.net>.

${ }^{26}$ The Constitution of Macedonia was altered in 1989 from "(Macedonia is) the state of the Macedonian people and the Albanian and the Turkish minorities" to read "(Macedonia is) the national state of the Macedonian nation." The Albanians demanded to be explicitly mentioned in the Constitution as a "Constituent Nation." In the 1946 and 1974 constitutions of the former Yugoslavia, constituent nations had the right to secede. No wonder the Macedonians rejected this formulation.
} 
nationalist indoctrination under the guise of religious instruction, pressuring other Muslims to declare themselves as Albanians, and irredentism. ${ }^{27}$

On top of these simmering tensions during much of the 1990s, there was the growing problem of Albanian refugees from Kosovo in Macedonia following Milošević's crackdown on Albanians in Kosovo and NATO's air campaign of March-June 1999. ${ }^{28}$ Repeatedly, the Macedonian government warned the international community that it could not allow more refugees on its soil, both for economic reasons and for fear of disrupting the fragile ethnic fabric of the country. In addition, there was a lot of evidence of massive arms smuggling activity in the Northern regions of Macedonia bordering Kosovo and Southern Serbia. Reports showed that Albanians in the Macedonian border villages were preparing themselves for an armed uprising. ${ }^{29}$ Finally, the international community failed to establish a link between the crisis of the Preševo Valley in June 1999 and a possible crisis in Macedonia. ${ }^{30}$ The attention of the European Union, indeed of the international community as a whole, was focused on Kosovo and Serbia, whereas Macedonia was regarded as a relatively stable country in the Western Balkans. While it is true that the European Commission, in the months preceding the crisis, was engaged in Macedonia with different projects, these actions did not prevent that inter-ethnic tensions reached fever pitch during the presidential elections of 17 November 1999 when the late President Boris Trajkovski's win was attributed by the opposition to mass electoral fraud among Albanian voters. ${ }^{31}$ Over the next year, Macedonia continued to run on dangerously high voltage. In that year, the National Liberation Army (the Macedonian version of the Kosovar Liberation Army) emerged, claiming equal rights for ethnic Albanians by force. There was sporadic ethnically motivated violence, in the form of terrorist bomb attacks.

\footnotetext{
${ }^{27}$ See the December 2001 Progress Report of Rome-based network "Ethnobarometer", published online as K Balalovska, A Silj and M Zucconi, 'Minority Politics in Southeast Europe: Crisis in Macedonia' (2002) <http://www.ethnobarometer.org>.

${ }^{28}$ Some 400,000 Kosovar refugees flooded into Macedonia (equal to 20 per cent of the population).

${ }^{29}$ See <http://www.macedonia.org/crisis/timeline.html>.

${ }^{30}$ The crisis surfaced after the end of the war in Kosovo, when Serbian military and police forces were withdrawn from Kosovo and deployed in the Preševo Valley and when the pressure of the Serbian administration on the Albanian families there increased, forcing them to leave a number of villages. From June 1999 onwards, thousands of Albanians fled, mostly to Kosovo and Macedonia.

${ }^{31}$ In the eyes of some the EU was even seen as siding with the Albanians by providing support to strengthen the administrative and judicial capacities and by contributing financial means to set up the South East Europe University in Tetovo, the first official university institute in Macedonia (partly) committed to the Albanian culture, language, and population. See <http://www.seeu.edu.mk/english/general/history.asp >.
} 
At the beginning of 2001, the Macedonian pressure cooker exploded. On 25 January, Albanian guerrillas claimed responsibility for a rocket attack on a police station which left one officer dead and wounded another three. On 11 February, the first sod was turned and construction of the disputed SEE University at Tetovo began. ${ }^{32}$ On 19 February, ethnic Albanian insurgents wearing the insignia of the NLA clashed with a military patrol in Macedonia. Due to the increasing violence, Macedonia put its troops on alert along the border with Kosovo to prevent ethnic Albanian fighters from infiltrating. Amid growing evidence that Albanian separatist guerrillas were using the Ground Safety Zone (GSZ) around Kosovo to stage incursions into both Southern Serbia and Macedonia, NATO agreed to start dismantling the buffer zone (Operation Eagle). ${ }^{33}$ At the fourth Summit of the Heads of State and Government of the South-East Europe Cooperation Process (SEECP), which - ironically - was held under Macedonian chairmanship in Skopje on 22 February 2001, all delegates (incl. Javier Solana and Chris Patten, then European Commissioner for External Relations) distanced themselves from the ethnic Albanian armed extremism and reiterated their strong attachment to the principle of inviolability of borders, including the territorial integrity of Macedonia. ${ }^{34}$ The European Union's presidency delivered tough warnings to Albanian leaders and called on all involved "to isolate the extremists". ${ }^{35}$ NATO Sec-

\footnotetext{
${ }^{32}$ Construction was completed within less than 6 months. This is even more remarkable when one considers that the Tetovo region witnessed some of the heaviest inter-ethnic skirmishes between March and August of 2001. The academic year started in October 2001 .

${ }^{33}$ At the end of NATO's air campaign against Serbia, the UN Security Council adopted UNSC Res 1244 (1999) which enabled NATO to deploy KFOR troops in Kosovo. Simultaneously, KFOR's First Commander, Sir Michael Jackson, and the Yugoslav military authorities agreed to, inter alia, the withdrawal of the Yugoslav army and police from Kosovo and the creation of a de-militarised, five-kilometre wide Ground Safety Zone in Western Montenegro and Southern Serbia along the border of Kosovo. See P Janković and S Gligorijević, 'Burying the Hatchet' (Summer 2004) NATO Review. A part of the GSZ, around the village of Tanuševci, in the corner where the borders of Kosovo, Southern Serbia, and Macedonia meet, had become a sort of no-man's land after the withdrawal of UNPREDEP, the UN's successful prevention force in the country. The NLA has prospered there thanks to different kinds of trafficking and other illegal activities. The pending ratification by the Macedonian parliament of a Yugoslav-Macedonian border agreement, which had been negotiated without the participation of the Albanians, was another reason for the NLA to launch an armed uprising. See R Detrez, Macedonië: land in de wachtkamer (Houtekiet, Antwerp 2002) 223.

${ }^{34}$ See <http://www.seecp.gov.mk>. The SEECP represents a comprehensive framework for regional cooperation aimed at close cooperation with other international organisations and regional initiatives. Of particular importance are the UN, EU, OSCE, NATO, the Council of Europe, the Black Sea Initiative, SECI, CEI, and BSEC.

${ }^{35}$ EU Bull. 1/2-2001, point 1.6.41. "The European Union urges all parties to respect the border demarcation agreement between the FRY and the Former Yugoslav Republic of Macedonia signed in Skopje on 23 February, and reiterates its strong attachment to the principle of inviolability of borders, including the territorial integrity of the Former Yugoslav Republic of Macedonia. A peaceful and stable Former Yugoslav Republic of Macedonia - within internationally recognised borders - is an important condition for furthering the integration
} 
retary General George Robertson called the rebels "a bunch of murderous thugs whose objective is to destroy a democratic Macedonia and who are using civilians as human shields" in a cynical bid to provoke "another Balkan bloodbath." 36 Strengthened by the international disapproval of NLA's actions, the Macedonian army called for a general mobilisation on 5 March and launched an offensive against the NLA's stronghold of Tanuševci. While the Macedonian army seized control of the village and its surroundings, it was not able to prevent the violence from spreading. ${ }^{37}$

The crowning achievement of the Albanians was their success in internationalising the conflict. In this, they were aided by a panic stricken Macedonian establishment. When the leaders of the NLA, at the end of March, emphasised that their sole goal for action constituted the protection of those rights for which they had been fighting by peaceful means for the past ten years, and not the ambition to create a "Greater Albania", they must have convinced the "wise men of the West" - Javier Solana, Lord Robertson, and US Secretary of State Colin Powell - to put pressure on the Macedonian government to start negotiations with the NLA to solve the conflict. ${ }^{38}$

\subsubsection{A partnership of "honest" brokers?}

At the beginning of April 2001, a number of EU representatives visited Skopje to prepare the signing of the Stabilisation and Association Agreement (SAA) with Macedonia on 9 April in Luxembourg. ${ }^{39}$ The SAA would establish legal obligations for Macedonia to approximate its legislation to the acquis communautaire and to cooperate with the other countries of the Western Balkans. It involved the perspective of the establishment of a free trade area between the European Community and the country, provisions on cooperation in a wide range of fields, including justice and

of the Former Yugoslav Republic of Macedonia within the European Union, soon through the signing of the Stabilisation and Association Agreement."

${ }^{36}$ As reported in "Macedonia 'on brink of abyss" BBC News (7 March 2001).

${ }_{37}$ The conflict spread out and in the ensuing months ethnic Albanian militants successfully "liberated" other villages in Northern Macedonia, including, in June, Ara ivono, from where they threatened to launch mortar attacks on the outskirts of Skopje and on the international airport.

38 See R Detrez, Macedonië: land in de wachtkamer (Houtekiet, Antwerp 2002) 230-231; and 'The Position of the EU and NATO On the Current Situation in the Republic of Macedonia' $<$ http://www.macedonia.org/crisis/story3.html>.

${ }^{39}$ Negotiations were closed on 24 November 2000 and the SAA was initialled at the same date, during the Zagreb Summit. See COM (2001) 90 final, Brussels, 19 February 2001. For an analysis of the SAA, see S Blockmans, 'Western Balkans' in S Blockmans and A Łazowski (eds), The European Union and Its Neighbours: A Legal Appraisal of the EU's Policies of Stabilisation, Partnership and Integration (T.M.C. Asser Press, The Hague 2006) 315-355. 
home affairs, and the provision of financial assistance to help Macedonia achieve the objectives of the Agreement. Macedonia was the first and at the same time the least prepared country which was offered such an agreement. It was meant to repair the shattered confidence of Macedonia in the European Union and to make the government more susceptible to Western diplomatic initiatives. Javier Solana, who had been "invited" by the European Council at its Stockholm summit of 23 and 24 March "to follow the situation in the region, to stay in close touch with the leaders and in consultation with the Commission and to make recommendations to the Council," ${ }^{40}$ used the prospect of the pending signature and ratification of the SAA as a strong lever to persuade the Macedonian government to engage in negotiations to reform the Constitution and establish equal rights for both communities. ${ }^{41}$ The Albanians found comfort in this approach because they expected that Macedonia would never accede to the EU if the Albanian question was not resolved according to "European standards." When the Macedonian government realised that negotiations on a political agreement with the Albanian militants had become unavoidable, it decided to build a government of national unity by expanding the existing government with moderate Albanian politicians. In this way, the coalition would share the responsibility for the amendments to the Constitution and other laws with the two biggest ethnic Albanian parties, and it would be able to find the necessary two-thirds majority needed to push the reforms through parliament.

While the fighting on the ground and talks on forming a grand coalition dragged on, Western diplomats tried to hammer out a politically acceptable implementation plan for the future accord. At the end of June, Robert Badinter, ${ }^{42}$ François Léotard - the freshly appointed EU Special Representative in Macedonia, ${ }^{43}$ and US Special Envoy James Pardew were sent to Skopje to mediate in the negotiations on a ceasefire and a political agreement between the parties to the conflict. ${ }^{44}$ The ceasefire agreement of 5 July was breached by Albanian extremists. This caused the negotiations to stall. As a reaction, the EU adopted punitive sanctions

\footnotetext{
40 See EU Bull 3-2001, point I.36.66.

${ }^{41}$ In line with the European Parliament's Resolution of 5 April 2001. See EU Bull 4-2001, point 1.6.1.

${ }^{42}$ Former President of the French Constitutional Court and President of the so-called "Badinter Arbitration Commission" which opined on the legal consequences of the dissolution of the SFRY. From November 1991 until July 1992, the Commission issued ten opinions, one interlocutory decision, and one comment concerning Croatia's constitutional law on minorities. All texts are published in 31 ILM (1992) 1494 following. See also S Terrett, The Dissolution of Yugoslavia and the Badinter Arbitration Commission: A Contextual study of Peace-making Efforts in the Post-Cold War World (Ashgate, Aldershot 2000).

43 Council Joint Action (CFSP) 2001/492,[2001] OJ L 180/1.

${ }^{44}$ In the meantime, an agreement on a broad coalition government had been struck. See EU Bull 5-2001, point 1.6.12.
} 
against the ethnic extremists. ${ }^{45}$ On 25 July, NATO's Special Envoy Peter Feith secured a limited ceasefire agreement in and around Tetovo. The following day, Solana and Robertson, accompanied by the Chairman-inOffice of the OSCE, Mircea Geoana, travelled to Skopje to blow new life into the negotiations. ${ }^{46}$ On 28 July, the negotiators decided to move the talks to Villa Biljana, on the idyllic shores of Lake Ohrid. Despite some heavy fighting in the first two weeks of August, a political deal was struck at Ohrid on 8 August.

It can be said that the new institutional framework for the CFSP and the ESDP allowed EU action in Macedonia to produce a more positive outcome than was the case in previous Balkan crises. Nonetheless, in terms of conflict prevention stricto sensu, the Union failed to identify, let alone address, some of the early signs which pointed to the possibility that a crisis might emerge in the FYROM, long before it actually did in January 2001. ${ }^{47}$ The Albanian armed insurgency amounted to low intensity warfare, but nevertheless created a humanitarian catastrophe when one considers the numbers of ethnic Albanian refugees which fled into Kosovo (approx. 65,000) and internally displaced persons in Macedonia (approx. 35,000). ${ }^{48}$ To a large extent, the Union's success in preventing the further escalation of violence into a full-blown civil war and in suppressing the conflict is thanks to its "preventive" diplomacy and the leading role played by Javier Solana. The SG/HR travelled to Skopje on countless occasions, sometimes accompanied by Chris Patten. Supported on the ground by François Léotard, the EU's resident envoy, and José Pinto Teixeira, Head of the Commission Delegation, the SG/HR put considerable pressure on both the Macedonian and the Albanian sides to engage in dialogue. ${ }^{49}$ The looming signature of the SAA between the EU and the FYROM was certainly the strongest incentive at Solana's disposal to force the two parties in the conflict to arrive at an agreement by political means. To this end, the Commission's brand-new Rapid Reaction Mechanism (RRM) was also utilised. ${ }^{50}$

45 Council Common Position concerning a visa ban against extremists in the Former Yugoslav Republic of Macedonia (CFSP) 2001/542 [2001] OJ L 194.

${ }^{46}$ See Presidency statement on behalf of the European Union on the situation in the Former Yugoslav Republic of Macedonia of 26 July 2001, in EU Bull 7/8-2001, point 1.6.10.

47 See eg S Clément, Conflict Prevention in the Balkans: Case Studies of Kosovo and the FYR of Macedonia (ISS, Paris 1997) 13-16 and 24-27. Clement draws the same conclusion about the limited preventive measures adopted by the international community, "in particular the European Union", in the case of Kosovo; at 21-23. See also S Clement, "Former Yugoslav Macedonia, the Regional Setting and European Security: Towards Balkan Stability?' in J. Pettifer (ed), The New Macedonian Question (Palgrave, Basingstoke 2001) 285-302.

${ }^{48}$ UNHCR estimates reported in IWPR 261, 4 July 2001.

49 See N Whyte, N Arbatova and D Allin, 'The Macedonian Crisis and Balkan Security', (2001) ESF Working Papers.

50 Council Regulation (EC) 381/2001 creating a rapid-reaction mechanism, [2001] OJ L $57 / 5$. The RRM allows the Commission to dispatch Community funds rapidly in case of an 
But the Union could not have managed to broker the peace deal at Ohrid without the support of NATO and, to a lesser extent, the US and OSCE. NATO's involvement was logical if one considers that KFOR's supply routes and logistical bases were in Macedonia. From a more geopolitical perspective, NATO's southern flank - comprising the ever adversarial Turkey and Greece - could be destabilised by an inter-religious conflict in the Balkans. Add to this the destabilising and radicalising impact upon the delicate fabric of Kosovo of the throngs of ethnic Albanian refugees from Macedonia, and Lord Robertson's active engagement becomes more understandable, as does his relentless pressure on local politicians to deliver a peace agreement.

\subsubsection{Ohrid Framework Agreement (2001)}

The Ohrid Framework Agreement was signed at a ceremony at the residence of President Trajkovski in Skopje on 13 August 2001. ${ }^{51}$ With their presence, Solana, Robertson, Geoana, Pardew, and Léotard emphasised the importance which the international community attached to the Agreement. The text of the Ohrid Framework Agreement contained a series of commitments - in the form of basic principles and legislative modifications, which parliament had to apply through constitutional amendments and implementing laws. Among the basic principles, the parties to the Agreement rejected the use of violence in pursuit of political aims, recognised Macedonia's sovereignty, its territorial integrity, and the multi-ethnic character of its society, and underlined the development of local self-government to encourage the participation of citizens in democratic life and promote respect for the identity of communities. The parties agreed to a complete cessation of hostilities, after which the ethnic Albanian armed groups would be completely disarmed and disbanded with the assistance of NATO. The rest of the Agreement was devoted to the more concrete revision of legislation on, inter alia, local self-government, ${ }^{52}$ the revision of municipal boundaries one year after a new census

emergency. It can be used both to conduct once-off actions arising out of a crisis situation, and to "kick-start" projects or programmes which will require longer-term follow-up through other assistance instruments. The RRM funds measures aimed at restoring the conditions of stability under which the main Community cooperation programmes can achieve their objectives. These can include measures to restore the rule of law, promote democracy and human rights, peace-building and mediation initiatives, the demobilisation and reintegration of combatants, the reconstruction of infrastructure and the strategic planning of the economic, administrative and social rebuilding of countries affected by crisis. The funds available through the RRM were $€ 20$ million for 2001 and $€ 25$ million for 2002 . The RRM was first used in March 2001 to pay for the reconstruction of houses destroyed or damaged by the fighting in the areas of Tetovo and Skopska Crna Gora.

${ }^{51}$ The Agreement is available at <http://faq.macedonia.org/politics/framework_agreement.pdf>.

52 To reinforce the powers of elected local officials and to enlarge their competences in the areas of public services, urban and rural planning, environmental protection, local economic development, culture, local finances, education, social welfare, and health care. 
(to be held by the end of 2001), and the employment in public administration. ${ }^{53}$

Special Parliamentary Procedures were agreed to for the amendment of the Constitution and the Law on Local Self-Government: a qualified majority of two-thirds of votes, "within which there must be a majority of the votes of representatives claiming to belong to the communities not in the majority in the population of Macedonia." 54 The same clause applied to the majority of votes required for the revision of laws affecting culture, the use of language, education, personal documentation, the use of symbols, as well as laws on local finances, local elections, the city of Skopje, and boundaries of municipalities.

With respect to primary and secondary education, instruction would be provided in the students' native languages. State funding would be provided for university level education in languages spoken by at least 20 per cent of the population of Macedonia. It was agreed that Macedonian would be the official language of the country. Any other language spoken by at least 20 per cent of the population was also recognised as an official language and said to be used for the communication with the central and with and/or within decentralised authorities. In criminal and civil judicial proceedings at any level, an accused person or any party was said to have the right to translation at state expense of all proceedings as well as documents. Local authorities were given the right to place on front of local public buildings, next to the emblem of the "Republic of Macedonia," emblems marking the identity of the community in the majority in the municipality.

The Constitutional amendments attached to the Ohrid Framework Agreement in Annex A had to be presented to parliament immediately. The parties obliged themselves to take all measures to assure the adoption of these amendments within 45 days of signature of the Agreement. The legislative modifications identified in Annex B were expected to be adopted in accordance with the timetables specified therein. Finally, the parties invited the international community to convene an international donor conference to address in particular macro-financial assistance and the financing of the measures to be undertaken for the purpose of implementing the Framework Agreement.

Annex $\mathrm{C}$ to the Framework Agreement contained a number of issues which concerned the international community. The parties "invited" the international community to facilitate, monitor, and assist in the imple-

${ }^{53}$ To assure the equitable representation of communities in all central and local public bodies, especially the police services, and at all levels of employment within such bodies, while respecting the rules concerning competence and integrity that govern public administration.

${ }^{54}$ Ohrid Framework Agreement, section 5.1. 
mentation of the provisions of the Agreement and its Annexes, and "requested" such efforts to be coordinated by the EU in cooperation with the newly established Stabilisation and Association Council. The Council of Europe and the European Commission were asked to supervise a census to be conducted. The OSCE and other international organisations were invited to send observers to the parliamentary elections of 2002. Furthermore, the parties pledged to work to ensure the return of refugees and internally displaced persons to their homes within the shortest possible timeframe and invited in particular UNHCR to assist in these efforts. The parties invited the EU, OSCE, and the US to support and assist with the implementation of the commitment to ensuring that the police services would by 2004 generally reflect the composition and distribution of the population of Macedonia, in particular through the screening and selection of candidates and their training. In addition, the EU, OSCE, and the US were also invited to deploy, as soon as possible, international monitors and police advisors in sensitive areas. Finally, the parties invited the international community to assist in the training of lawyers, judges, and prosecutors from members of communities not in the majority in Macedonia in order to be able to increase their representation in the judicial system.

A major flaw in the Framework Agreement came in the form of the special governmental privileges (in respect of education and the use of languages): as said, they were only granted to minorities making up "at least 20 per cent of the population." 55 Ironically, the Agreement in the preamble asserted that it "will promote the peaceful and harmonious development of civil society while respecting the ethnic identity and the interests of all Macedonian citizens." With thousands of Macedonian citizens of various ethnic backgrounds who make up less than 20 per cent of the population, ${ }^{56}$ the Ohrid Framework unequivocally discriminated against these citizens. ${ }^{57}$

\subsubsection{Sustainability of the diplomatic efforts}

While the Ohrid Framework Agreement has been criticised as a continuation of "the infamous tradition of compacts imposed by a war-weary

\footnotetext{
55 Ohrid Framework Agreement, section 6.

${ }^{56}$ Macedonian 64.2 per cent, Albanian 25.2 per cent, Turkish 3.9 per cent, Roma 2.7 per cent, Serb 1.8 per cent, other 2.2 per cent (2002 census). See CIA World Factbook, available at <http://www.cia.gov/cia/publications/factbook/geos/mk.html>.

${ }^{57}$ See S Gligorov and M Koloski, 'Decentralization, or Euro-Discrimination?' 4 November 2004 <http://www.maknews.com/html/articles/koloski/koloski8.html>.

last accessed 19 March 2006: "Public pressure against fulfilment of the Framework Agreement surfaced in the form of large public protests against race-based decentralisation. The Constitutional requirement for Referendum put democratic power back in the hands of the people when over 150,000 signed a petition against the Framework."
} 
West on helpless and hapless small nations" and was doomed to fail, 58 it did, in the medium term, ${ }^{59}$ bring an end to several months of violence between ethnic Albanian groups and the state security forces. In the second half of 2001, NATO collected 4,000 pieces of weapons from the NLA (Operation Essential Harvest).

The Ohrid Framework Agreement provided for a decentralised system of governance, an equitable representation for ethnic Albanians in the Macedonian state structures, and the recognition of the Albanian language and culture. It is true, however, that additional "carrots and sticks" were necessary to persuade the former rivals to adhere to their commitments. In October 2001, for example, the Commission adopted a decision to finance a Confidence Building Programme for Macedonia, including the use of funds of the RRM. This package worth $€ 10.3$ million was inextricably linked to the full ratification of all the amendments to the Macedonian Constitution (16 November 2001), as well as the new Law on Local Self-Government (24 January 2002). ${ }^{60}$ Withholding financial incentives by postponing the donor conference to which the international community had been "invited" proved another useful tool to clear hurdles in the implementation process of the Framework Agreement. At that conference, which was held in Brussels on 12 March 2002, the international community pledged $€ 307$ million to reform in Macedonia - $€ 50$ million more than the country had asked for ${ }^{61}$ Finally, the threat by the European Union to revise the one-year old SAA was another (doubtful) method used by the Union to cajole the Macedonian parliament into adopting the necessary laws on the use of languages in April 2002. ${ }^{62}$

After a series of constitutional amendments and changes to more than 70 laws, the adoption of the law on use of flags of the communities on 15 July 2005 meant that Macedonia completed the legislative agenda set out in the Ohrid Framework Agreement. ${ }^{63}$ Despite the criticism on the

58 See S Vaknin, 'Macedonia's Framework Agreement' 20 August 2005, http://www.globalpolitician.com/articleshow.asp?ID=1106\&cid=3\&sid=10 last accessed 19 March 2006.

${ }^{59}$ In the months following the signing of the Ohrid Framework Agreement, ethnic Albanian gangs continued with isolated armed provocations and terrorist attacks, such as setting bombs in residential areas and intimidating Slavic Macedonians by destroying their homes and preventing their safe returns.

${ }^{60}$ European Commission Conflict Prevention and Crisis Management Unit, Rapid Reaction Mechanism End of Programme Report Former Yugoslav Republic of Macedonia, November 2003 <http://europa.eu.int/comm/external_relations/cpcm/rrm/fyrom.pdf>.

61 Ibid.

62 See R Detrez, Macedonië: land in de wachtkamer (Houtekiet, Antwerp 2002) 257.

${ }^{63}$ See SG/HR's statement to mark the occasion, S259/05, 15 July 2005: "While the completion of the legislative agenda of the Framework Agreement marks the end of an important process, it does not mean that the Ohrid agenda is fulfilled. Mission accomplished can only be declared when rules are respected, realities on ground have changed, and long-term reforms such as decentralisation and equitable representation have been fully carried out. 
Ohrid Framework Agreement, its implementation has spurred a process of rapid stabilisation and normalisation of the situation in Macedonia. ${ }^{64}$ The country is now definitely in much better shape than in 2001. Instead of facing a destructive conflict, it is currently engaged in a constructive effort to gain membership of the European Union. It is to be hoped that the basis for this rapid transformation process, the principles of multiethnicity, sovereignty, and territorial integrity of Macedonia, as laid down in the Framework Agreement, will stand the test of time.

\subsection{The death of the third "Yugoslavia" 65}

\subsubsection{The need to restructure relations between Serbia and Montenegro}

The relations between Belgrade and Podgorica had been deadlocked ever since Milo Djukanović and his Democratic Party of Socialists (DPS) beat Milošević's confederates in Montenegro on a pro-independence ticket in the 1997 presidential and the 1998 parliamentary elections. ${ }^{66}$ Djukanovic's victory revealed the fundamental flaw of the Federal Republic of Yugoslavia, the two-state federation created in April 1992 from the remainder of Tito's Socialist Federal Republic of Yugoslavia: the equality of the two unequal partners in the federation. ${ }^{67}$ Between the inaugura-

Further clarification might be needed in the area of use of languages. Tackling these challenges will form part the future European reform agenda."

${ }^{64}$ From the side of the Council, this process was overseen by a series of EU Special Representatives. By Council Joint Action (CFSP) 2001/760 of 29 October 2001[2001] OJ L 287, Alain Le Roy was appointed as the EUSR in Macedonia to replace François Léotard. One year later, Le Roy was replaced by Alexis Brouhns; see Council Joint Action (CFSP) 2002/832 of 21 October 2002 [2002] OJ L 258/12. Brouhns' mandate was prolonged and widened by Council Joint Action (CFSP) 2002/963 of 10 December 2002 [2002] OJ L 334/7 and Council Joint Action (CFSP) 2003/870 of 8 December 2003 [2003] OJ L 326/39, inter alia to draw clearer lines of command and to give guidance to the first ESDP missions in the country (see chapter 3.2 below). Brouhns was replaced by Michael Sahlin; see Council Joint Action (CFSP) 2004/565 of 26 July 2004 [2004] OJ L 251/18, who was replaced by Erwan Fouéré by way of Council Joint Action (CFSP) 2005/724 of 17 October 2005 [2005] OJ L 272/26. Fouéré was also appointed Head of the European Commission's delegation in Skopje.

65 The facts described in this section are primarily based on the Balkan Crisis Reports of the London-based Institute for War \& Peace Reporting <http://www.iwpr.net>.

${ }^{66}$ See F Bieber, 'Montenegrin Politics Since the Disintegration of Yugoslavia' in F Bieber (ed), Montenegro in Transition: Problems of Identity and Statehood (NOMOS, Baden-Baden 2003) 11-42.

67 Serbia is 16 times bigger than Montenegro in terms of population and 6 times in terms of landmass. See CIA World Fact Book, available at <http://www.cia.gov/cia/publications/ factbook/geos/yi.html>. Anno 2006, the population of Serbia and Montenegro stands at roughly 10.5 million with approximately 8 million living in Serbia, 1.9 million in Kosovo, and 600,000 in Montenegro. The total landmass is $102,350 \mathrm{sq} \mathrm{km}$ : Serbia accounts for $77,535 \mathrm{sq} \mathrm{km}$, Kosovo for 10,877 sq km, Montenegro for 13,938 sq km. 
tion of Djukanović as President of Montenegro in January 1998 and the fall of Milošević two and a half years later, tensions between Serbia and Montenegro steadily increased. In the light of the escalating conflict in Kosovo and the participation of the Serbian Radical Party in the Serbian government in early 1998, the Serbian authorities adopted an increasingly belligerent tone, using the considerable army presence in Montenegro to put pressure on the republican authorities. ${ }^{68}$ Simultaneously, the Djukanović government adopted an increasingly independence-minded policy, leading eventually to the outright call for Montenegro's secession from Serbia. ${ }^{69}$ Montenegro effectively ended most economic ties with Serbia, inter alia by adopting the German Mark in November 1999 as a parallel currency - and, as of November 2000, as an exclusive one (before switching to the Euro in early 2002). ${ }^{70}$ In response, Serbia established checkpoints at the border between the two republics and started collecting customs - thus, in fact, re-affirming Montenegro's independence in all but name. The FRY had become a dead letter.

The deadlock in relations between Belgrade and Podgorica became an acute political dilemma after Milošević was removed from the presidential peluche in the wake of the epochal elections in October 2000. In the course of just a few months, all major players managed to manoeuvre themselves into an untenable position. Djukanović, expecting Milošević to win, had boycotted the federal elections. As a consequence, his natural allies, the reform-oriented and pro-Western Democratic Opposition of Serbia (DOS), took over power in Serbia but had to make a coalition at the federal level with the reactionary Montenegrin opposition. The reform drive and international credibility of the political programme of the late Zoran Djindjić, the new Prime Minister of Serbia, fell prey to the stand-off over competences between federation and republic. The newly installed President Vojislav Koštunica saw his lead in popularity diminish in comparison with Djindjić and other younger reformers - a development partly due to the powerlessness of his position. The nationalist opposition of

${ }^{68}$ See E Schmitt, 'Crisis in the Balkans: The Military; NATO Commander Says Milošević is Moving Forces Into Pro-Western Montenegrin Republic', New York Times (2 July 1999); and 'Armed Yugoslav Troops Take over Montenegro's Main Airport', New York Times (9 December 1999).

${ }^{69}$ See S Erlanger, 'Montenegrins See Split with Serbia', New York Times (18 October 1999).

70 The dispute over Montenegro's status has been considerably informed by economic considerations. See B Huszka, 'The Dispute over Montenegrin Independence', in F. Bieber (ed), Montenegro in Transition: Problems of Identity and Statehood (NOMOS, Baden-Baden 2003) 43-62. The successful introduction of the Euro is by no means an indication of economic strength or aptitude: Podgorica is not bound by any criteria of economic convergence. The currency is more convenient for legal and not-so-legal international dealings than for an ailing local economy. See ICG, 'Montenegro's Independence Drive', 7 December 2005 Europe Report No 169. 
former Milošević parties witnessed the once proud Yugoslavia become defunct, with a quasi-independent state in Montenegro and a quasi-protectorate in Kosovo. In Podgorica, his narrow victory on 22 April 2001 in the parliamentary elections and the rising popularity of the Socialist People's Party of Montenegro (SNP) in the polls determined Djukanović's reluctance to implement his promise for a referendum on independence. ${ }^{71}$ Thus, after the euphoria at the end of 2000 of finally having democratic negotiation partners and two constructive and apparently compatible platforms, ${ }^{72}$ the actual talks between Belgrade and Podgorica soon stalled in a "consent not to consent." As all players came to realise that they had manoeuvred themselves into a "lose-lose" situation, the perspective of closer relations with the EU provided economic incentives as well as a welcome excuse to accept mediation from the EU's High Representative for the CFSP.

\subsubsection{The EU as an honest broker?}

From December 2001 onwards, when Javier Solana took on the "mission impossible" to find middle ground between Belgrade and Podgorica and prevent a spring referendum on the independence of Montenegro, criticism grew louder and louder. No doubt, Solana's role went far beyond merely offering "good offices." ${ }^{73}$ As participants to the negotiations have indicated, Solana often dangled the carrot of opening negotiations on a prospective Stabilisation and Association Agreement between the FRY and the EU, with its immediate economic advantages and its alluring promise of future EU membership. ${ }^{74}$ But the SG/HR was also reported

\footnotetext{
${ }^{71}$ See M Tadić, 'Montenegrin Independence on Hold' (2001) 240 IWPR Balkan Crisis Report.

72 The Montenegrin negotiation position was brought to paper by Djukanović on 29 December 2000. The joint reply by federal President Koštunica and Serbian Prime Minister Djindjić was presented on 10 January 2001. The full texts of both positions are reproduced in CEPS Europa South-East Monitor, Issue 19, January 2001. Typically, whereas the Djukanović platform dwelled on the injustices of past Montenegro-Serbia relations and Montenegro's "inalienable right to self-determination," the preamble of the response by Koštunica and Djindjić highlighted the merits of federal arrangements, the historic and cultural ties as well as joint economic interests.

${ }^{73}$ In its original meaning, good offices aim at the initiation or resumption of negotiations only, with no active participation of the third party. In a mediatory process, on the other hand, the third party tries to bring the conflicting parties to an agreement for peaceful settlement by actively participating in the process of negotiations. In practice, however, the borderline between the two methods is often blurred. Nowadays, the term "good offices" is generally accepted to mean the supply of mediation services by persons of high moral standing and acknowledged impartiality to find an amicable settlement of a dispute between states.

${ }^{74}$ See G Barrett, 'EU and Serbia and Montenegro' in D Lopandi and V Baji (eds), Serbia and Montenegro on the Road to the European Union - Two Years Later (European Movement in Serbia, Belgrade 2003) 37-45.
} 
to have threatened Montenegro with cutting off at least half of the EU's financial aid if Podgorica pursued its plans to stage a referendum on independence. ${ }^{75}$ On 14 February 2002, the Brussels-based Centre for European Policy Studies (CEPS) and International Crisis Group (ICG) published an open letter to the SG/HR concerning Montenegro. ${ }^{76}$ One part of the think tanks' critique concerned Solana's methods of applying extreme pressure to just one side in order to "bulldozer" Podgorica towards the EU's preferred solution. In their view, the European Union used its hegemony as a regional economic power to force a state union on "unwilling partners." 77 The other half of the critique concerned the dictated outcome of the negotiations: "a democratic Montenegro in a democratic (FR)Yugoslavia." 78 This solution was considered "economically and politically unwise." ${ }^{\prime 9}$ Solana's attempts to keep Serbia and Montenegro together were more often than not understood as blunt efforts to save the status quo, with some minor, cosmetic modifications. Consequently, the EU would end up polarising the parties and supporting the line of the reactionary SNP nationalists in Montenegro and the parties of the former Miloševi coalition in Serbia.

Once both Koštunica and Djindjić had expressed their willingness to consider a new form of federation with Montenegro (albeit not at all cost), Solana indeed ended up siding with the reactionary forces on the federal level and in Montenegro, cajoling the pro-independence parties into making major concessions to their programme. ${ }^{80}$ Publicly, the EU failed to distance its stabilisation objective from the die-hard conservatism of the local pro-Yugoslav forces. Nevertheless, the final agreement, which constituted a compromise between the two original position papers, ultimately favoured the reformers rather than the reactionaries. The "creation" of the new state union of "Serbia and Montenegro" and a temporary freezing of the status issue allowed pro-Western politicians in both republics to pursue their reform agendas with more zeal.

\subsubsection{Belgrade Agreement (2002)}

A document called "Proceeding Points for the Restructuring of Relations Between Serbia and Montenegro" - commonly known as the Bel-

${ }^{75}$ See M Tadić, 'Montenegro: Djukanović Cornered over Independence' (2002) 319 IWPR Balkan Crisis Report.

${ }^{76}$ The open letter is reproduced in CEPS Europa South-East Monitor, Issue 31, January/ February 2002.

77 Ibid.

${ }^{78}$ See Council Conclusions throughout 2001, published in EU Bull 2001.

${ }^{79}$ CEPS Europa South-East Monitor, Issue 31, January/February 2002.

80 See M Wisse Smit, 'Comment: Squabbling Yugoslav Republics Set for Divorce' (2002) 322 IWPR Balkan Crisis Report. 
grade Agreement, after the place were it was signed on 14 March 2002 - was the outcome of the trilateral negotiations among the governments of Serbia, Montenegro, and the Federal Republic Yugoslavia with the SG/ HR as mediator and "witness" to the agreement. ${ }^{81}$ In the most principal set of issues, international status and representation, the Belgrade Agreement contains only one short reference to "elements of Serbian and Montenegrin statehood, stemming from the present-day factual situation and the historic rights of the two member states." The Agreement largely follows the Serb position with a veto on unilateral secession. Montenegro was not granted its desired international legal personality, but in return, Serbia (and the European Union) accepted the option of a referendum on independence three years after the adoption of the Constitutional Charter which was to implement the Agreement. To protect Montenegro's interests from being swamped by Serb domination of the joint institutions and international representative positions, specific safeguards were built in for proportional representation by rotation.

As far as the more tangible issues of the relations between the federation and the composite republics and the division of competences are concerned, the Belgrade Agreement is largely uninformative. The range of joint competences and ministries - defence, foreign affairs, internal and international economic relations as well as human and minority rights (including cooperation with the ICTY) - copied the Montenegrin proposal, with the exception of the common market and the convertible currency (Euro). As the composite republics were allowed to keep their separate economies, currencies, and customs services, the actual competences of the federation in internal and international economic relations were not clearly formulated. In the sphere of defence, conscripts would not be forced to serve outside their own republic against their will. There would be only one federal army - a lesson from Bosnia.

In terms of state institutions and decision-making, the Belgrade Agreement followed the more pragmatic Serbian approach based on operability rather than a strict interpretation of equality. The impracticable mode of the two republican ministers of defence and foreign affairs taking turns at the respective nominal position on the federal level was replaced by an "exchange of roles" by these two federal ministers and their respective deputies (from the other republic). In line with the limited compe-

${ }^{81}$ The Proceeding Points for a Restructuring of Relations between Serbia and Montenegro have been reproduced in CEPS Europa South-East Monitor, Issue 31, January/February 2002. For further analyses and commentaries, see eg N Bentzen, Fata Solana. Die Staatsunion Serbien-Montenegro - eine Spiegelung zwischen "Balkan" und EU? (Interdisziplinäre Balkanstudien - IDM Vienna University, Vienna 2004) <http://homepage.univie.ac.at/Vedran.Dzihic/balkan_bentzen.pdf>; and W van Meurs, 'The Belgrade Agreement: Robust Mediation Between Serbia and Montenegro' in F Bieber (ed), Montenegro in Transition: Problems of Identity and Statehood (NOMOS, Baden-Baden 2003) 63-79. 
tences of the federal government the Belgrade Agreement did not foresee a prime minister. The supervision of the ministerial council would be in the hands of the president. The unicameral parliament elected by all citizens of the federation pointed in the same direction, ignoring demands for a parallel system of republican parity next to individual democratic rights.

In short, apart from the clear decision to rename the FRY, most of the contentious issues had been left open, awaiting a constructive negotiation process to fill in the gaps. Thus, the Belgrade Agreement was essentially a declaration of intent rather than a constitutional blueprint. The modalities for achievement of the goals set out in the Agreement were to be elaborated in parallel with the Constitutional Charter. The substantiation of the Agreement by a mixed commission from the two republican parliaments and the federal parliament proved no easy task. ${ }^{82}$ The commission presented a Constitutional Charter in June 2002. Thereafter, newly elected republican parliaments and eventually a federal parliament elected by the entire constituency of "Serbia and Montenegro" passed democratic judgment on the new federation. The Constitutional Charter was adopted and proclaimed on 4 February 2003 by the Parliament of Serbia and Montenegro. ${ }^{83}$

2.2.4. Sustainability of the EU's diplomatic efforts in view of the ongoing drive for an independent Montenegro

The Belgrade Agreement left a number of questions unanswered. An obvious question concerned the state's ambiguous character between federation and confederation. Effectively, "Serbia and Montenegro" was a continuation of the 1992 Federal Republic of Yugoslavia. ${ }^{84}$ At the same time, however, the fact that the Constitutional Charter had to be passed by the parliaments of the composite republics after elections indicated an institutional break with the past. Many in Serbia, nostalgic for the days of Tito, regretted the loss of the name "Yugoslavia" and the ideal of a multiethnic state it once implied. To others in the region, "Yugoslavia" stood only for Serb ethno-nationalism and ethnic cleansing. After the extradi-

\footnotetext{
${ }^{82}$ For an elaboration on the open questions, hidden caveats and difficult negotiation process, see W van Meurs, 'The Belgrade Agreement: Robust Mediation Between Serbia and Montenegro' in F Bieber (ed), Montenegro in Transition: Problems of Identity and Statehood (NOMOS, Baden-Baden 2003) 73-78; and G Noutcheva, 'Negotiating a Viable State Union of Serbia and Montenegro' (2002) CEPS Commentary.

${ }^{83}$ See Official Gazette of Serbia and Montenegro No 1 of 4 February $2003<$ http://www. osce.org/documents/fry/2003/02/133_en.pdf>.

For the EU's reaction, see Council Conclusions Press Release 6604/03 (Presse 52) 24 February 2003

${ }^{84}$ Recognised by not only by the EU, but also the UN. SaM took the seat of the FRY in the GA.
} 
tion of Miloševi , dropping the name "Yugoslavia" was a second reassuring symbol, a farewell to the era of ethnic conflict and human tragedy. Of course, the argument that Yugoslavia in its three forms - the Kingdom of Serbs, Croats and Slovenes (1918-1945), the Socialist Federal Republic of Yugoslavia (1945-1992), and the Federal Republic of Yugoslavia (19922002) - was a historic error or that the FRY was an anti-European and anti-democratic state, reintroduced the ideal of nation-states through the backdoor.

Another deficit of the Belgrade Agreement concerned the economic integration of the two composite republics: each member of the state union retained its own economic, financial and customs systems, and Montenegro the Euro. Both the EU mediators and the negotiating parties clearly gave priority to easing tensions over the status question, hoping that new economic momentum spurred by the Stabilisation and Association Process would make up for the evident disadvantages of economic separation. ${ }^{85}$

The principal question related to the impact of the Belgrade Agreement on stability in the region. One of the reasons why the EU had strongly objected to the idea of Montenegrin independence ever since Djukanović took office, although the Badinter Commission had confirmed Montenegro's right to self-determination, ${ }^{86}$ was concern that allowing a referendum on independence would create further tensions within a very divided society. ${ }^{87}$ The chief reason, however, was the EU's worry for a precedent followed by yet another round of state fragmentation in a region traditionally suffering from too many projects of state- and nation-building. The EU was afraid that unravelling the Yugoslav federation would open the way to independence for unstable Kosovo, potentially even Republika Srpska. Kosovo's unresolved status was the main obstacle for Montenegro's independence, although political leaders in Podgorica and Priština never tired of denying any such nexus. ${ }^{88}$

What the Belgrade Agreement achieved was gaining time rather than playing for time. It erased the illusion of a viable FRY and it stabilised relations between the two republics. The Agreement, as given hands and

\footnotetext{
${ }^{85}$ See D Reljić, 'Serbien und Montenegro einigen sich über zukünftige staatliche Gemeinschaft' (2002) SWP-Brennpunkte. On the Stabilisation and Association Process, see S Blockmans (n 39).

${ }^{86}$ See 31 ILM (1992), 1494 following.

87 The high cost of integrating an independent Montenegro into the EU has been mentioned as another reason for the Union's opposition. See M Wisse Smit, 'Comment: Squabbling Yugoslav Republics Set for Divorce' (2002) 322 IWPR Balkan Crisis Report.

${ }^{88}$ Recent history has shown that, indeed, Kosovar politicians do not abandon their aspirations for independence, no matter what kind of constitutional acrobatics the Montenegrins perform.
} 
feet by the Constitutional Charter of Serbia and Montenegro, prescribed a three-year cooling-off period before any of the composite republics could hold a referendum on independence. ${ }^{89}$ Even if the new state union were only a transitional solution, it ended the constitutional confusion and political deadlock, without impeding the progress of either towards European integration. ${ }^{90}$ Most importantly, it gave the international community time to find a way to tackle the final status question for Kosovo. The price which the EU was willing to pay for that was the acceptance of secession by Montenegro, counter to international rules on the inviolability of borders, as long as the vote would be "legitimate", i.e. represent a 50 per cent threshold for participation and 55 per cent for approval for any result. ${ }^{91}$

In the end, the Belgrade Agreement was a mere stopgap before Montenegro held its independence referendum on 21 May 2006. In a narrow victory, 55.5 per cent of Montenegro's voters said they wanted independence and thereby effectively made an end to the state union with Serbia. The EU, OSCE and neighbouring countries congratulated Montenegro on the free and fair manner in which the referendum was conducted and expressed their satisfaction with the high turnout ( 86.49 per cent). ${ }^{92}$ In a special session on 3 June, and pursuant to Article 60 of the Constitutional Charter, the parliament in Podgorica passed a declaration on the independence of the Republic of Montenegro. On 5 June, the parliament in Belgrade declared the Republic of Serbia the legal successor to the state union and gave all state institutions 45 days to complete the separation. Under the terms of the Constitutional Charter, Serbia inherited membership of the UN and other international organisations, leaving Montenegro to apply in its own right. On 12 June, the Council of the EU recognised that the parliamentary acts were taken in conformity with the arrangements and the procedures foreseen in the 2002 Belgrade Agreement and with Article 60 of the Constitutional Charter. Hence, the Council gave the Member States the go-ahead for the recognition of the two new Balkan

\footnotetext{
${ }^{89}$ Incidentally, it gave the pro-independence movement in Montenegro ample time to prepare for a referendum.

${ }^{90}$ In the period from the signing of the Belgrade Agreement to the adoption of the so-called "twin-track approach" in November 2004, the effectiveness of the Union's approach towards SaM did, however, suffer from incoherence and inconsistencies between the demands from the SG/HR and the Council on the one hand, and the European Commission on the other. See N Tocci, 'EU Intervention in Ethno-political Conflicts: the cases of Cyprus and SerbiaMontenegro' (2004) 9 EFA Review 551-573; and R Keane, 'The Case of the Solana Process in Serbia and Montenegro: Coherence in EU Foreign Policy',(2004) 11 International Peacekeeping 1-17.

${ }^{91}$ See Council Conclusions Press Release 6344/06 (Presse 46) 27 February 2006.

${ }_{92}$ Croatia is particularly pleased, as it should lead to the rapid resolution of the long-standing dispute over the Prevlaka peninsula, occupied by the "Yugoslav" army in 1991 and which Belgrade has refused to return despite the urging of the Montenegrin government. Croatia formally recognised Montenegro on 12 June.
} 
states. It is expected that it will soon also approve the Commission's new mandates to continue the Stabilisation and Association Process separately with Montenegro and Serbia.

Fifteen years since the break-up of Yugoslavia, Montenegro is both lucky and unfortunate. It is lucky because it has achieved independence while avoiding war; it has not seen inter-ethnic relations poisoned by ethno-nationalist mobilisation as elsewhere in the former Yugoslavia. ${ }^{93}$ It is unfortunate because its economic and social situation leaves it in a precarious position. Despite a series of political, administrative and economic reforms, Montenegro still is among the world's best in terms of international assistance per capita ${ }^{94}$ It will take years before Montenegro will be in the position to join the EU. Serbia, which finds itself in a similar unenviable position economically, has the additional political problem of the breakaway province Kosovo. Serbia is currently conducting face-to-face negotiations with the Kosovo Albanians on finding a peaceful solution for the status of Kosovo. It is to the EU's role in this negotiating process that the paper now turns.

\subsection{The EU in Kosovo}

\subsubsection{Embedded in an international reconstruction effort}

The violence in Kosovo which led to the NATO campaign against the Federal Republic of Yugoslavia triggered important qualitative changes in the European Union's policy towards South East Europe as a whole. If the US and NATO had done the dirty work of defeating Miloševi militarily, the EU offered what the rest of the international community expected it to do: to generate economic growth and political stability in the region. ${ }^{95}$ By initiating the Stability Pact for South Eastern Europe, the EU resur-

\footnotetext{
${ }^{93}$ See F Bieber, 'Preface' in F Bieber (ed), Montenegro in Transition: Problems of Identity and Statehood (NOMOS, Baden-Baden 2003), 7-9.

94 See ICG, 'Montenegro's Independence Drive' (7 December 2005) Europe Report No 169: "Accusations of simulated reforms to please Western donors seem plausible. A significant part of economic activity - an estimated 40 to 60 per cent - is related to black market, mainly car rackets and cigarettes smuggling. The involvement of political parties and state administration is a foregone conclusion. The state needs foreign aid for social peace in a poverty-ridden country of rising unemployment, frequent electric power cuts and high inflation. Its economic openness (3 per cent tariff average) may be an asset, but tourism certainly is not its main industry at the moment."

95 See Agreement on the principles (peace plan) to move towards a resolution of the Kosovo crisis presented to the leadership of the Federal Republic of Yugoslavia by the President of Finland, Martti Ahtisaari, representing the European Union, and Viktor Chernomyrdin, Special Representative of the President of the Russian Federation, UN Doc S/1999/649 (3 June 1999).
} 
rected the idea of the "hour of Europe." ${ }^{96}$ Adopted on 10 June 1999, the day that NATO's air campaign against Serbia came to an end, the Stability Pact's founding documents solemnly declared that "[t]he EU will draw the region closer to the perspective of full integration of these countries [in South East Europe] into its structures." ${ }^{97}$ However, it was very much unclear how the Stability Pact squared with integration. It remained, by and large, a regional post-conflict reconstruction strategy funded by the international financial institutions, the EU and its Member States. ${ }^{98}$ In terms of its approach, the Stability Pact was not an accession platform. Although initiated by the German Presidency of the EU and sanctioned by the European Council at its Cologne summit, ${ }^{99}$ it was placed institutionally under the umbrella of the OSCE. The EU was just one, albeit the most important, stakeholder amongst many. In fact, the Stability Pact exemplified a trend for the EU in Kosovo: in July 1999, the Council of Ministers fulfilled the UN Secretary-General's wish to entrust to the Union the task of managing the economy pillar within the UN's administration in Kosovo, ${ }^{100}$ thus sharing responsibility for the reconstruction of Kosovo with a vast range of international actors.

On the same day as the Stability Pact was launched, the United Nations Security Council passed Resolution 1244 (1999), authorising the United Nations Interim Administration Mission in Kosovo (UNMIK) to begin a long process of building peace, democracy, stability, and self-government, designed to determine Kosovo's future status. ${ }^{101}$ By deciding that a political solution to the Kosovo crisis would have to take account of the Rambouillet Accords ${ }^{102}$ and would have to be based on the general principles developed by the G- $8,{ }^{103}$ as further elaborated in the principles

96 Declaration of Jacques Poos, Luxembourg's Foreign Minister, to the international press, 29 June 1991.

${ }_{97}$ For the final text of the Stability Pact of 10 June 1999, see <http://www.stabilitypact. org $>$. The quote is to be found on page 20 of the text. For more on the Stability Pact, see D Phinnemore and P Siani-Davies, 'Beyond Intervention? The Balkans, the Stability Pact and the European Union' in P Siani-Davies (ed), International Intervention in the Balkans Since 1995 (Routledge, London 2003) 172-193.

98 See D Bechev, 'Between Enlargement and CFSP: the EU and the Western Balkans' (paper presented at the LSE European Foreign Policy conference, 2-3 June 2004).

99 EU Bull 6-1999, point I.26.71.

100 Council Joint Action (CFSP) 1999/522 concerning the installation of the structures of the UNMIK of 29 July 1999 [1999] OJ L 201/1.

101 (10 June 1999) S/RES/1244.

102 Rambouillet Accords: Interim Agreement for Peace and Self-Government in Kosovo, UN Doc S/1999/648 (7 June 1999). The Accords were concluded under the auspices of the members of the Contact Group and the EU.

${ }^{103}$ See Statement by the Chairman on the conclusion of the meeting of the G- 8 Foreign Ministers held at the Petersberg Centre reproduced in Annex 1 to UNSC Res 1244 (on 6 May 1999). 
and other required elements in Annex 2 to the Resolution, the Security Council endorsed what later became known as the so-called "standards before status" policy. In essence, Kosovo was expected to make progress on the eight standards to be achieved by the Provisional Institutions of Self-Government (PISG) before its final status could be addressed. Those standards concerned: functioning democratic institutions; rule of law; freedom of movement; returns and reintegration; economy; property rights; dialogue with Belgrade; and the Kosovo Protection Corps. ${ }^{104}$ The implementation of the "standards before status" policy was the core political project of UNMIK and was given new momentum by the adoption of the Kosovo Standards Implementation Plan (KSIP) of 31 March 2004. ${ }^{105}$

In the first-ever operation of its kind, the UN brought together four so-called "pillars" under overall UNMIK leadership: ${ }^{106}$ police and justice (Pillar I) and civil administration (Pillar II) under the direct responsibility of the UN; ${ }^{107}$ democratisation and institution-building (Pillar III) under the responsibility of the OSCE; and economic reconstruction, recovery, and development (Pillar IV) under the responsibility of the European Union. ${ }^{108}$ The work of the EU in Pillar IV has been geared towards modernising the economic framework of Kosovo, with a view to developing the

104 The "Standards for Kosovo" were agreed between the PISG and UNMIK and subsequently launched by the Special Representative of the Secretary General (SRSG) Harry Holkeri and Kosovo's Prime Minister Bajram Rexhepi on 10 December 2003. See Press release UNMIK/ PR/1078 of that date. The "Standards" were endorsed by the Security Council on 12 December 2003. See Presidential Statement S/PRST/2003/26.

105 The KSIP is available at <http://www.unmikonline.org/standards>. The document describes the concrete actions which must be taken in order to meet the "Standards". It clearly defines who is responsible for each of the actions and the timeframe in which they should be performed. In the light of the riots of March 2004 and an extensive review of their causes and consequences, the goals and actions which most support "sustainable multiethnicity" were prioritised for the review of mid-2005.

${ }^{106}$ UNMIK is headed by the SRSG. Bernard Kouchner (France) served as head of UNMIK from July 1999 to January 2001. The second head of the UN Mission was Hans Haekkerup (Denmark) who served from February 2001 to December 2001. Michael Steiner (Germany) served from January 2002 to July 2003. Harri Holkeri (Finland) served from August 2003 to June 2004. From 16 August 2004 until the end of June 2006, Søren Jessen-Petersen (Denmark) presided over the work of the four integral pillars of UNMIK and facilitates the political process designed to determine Kosovo's future status. On 12 June he announced his resignation. At the time of writing, his successor was not yet known.

107 Pillar II has since been integrated into the Office of the SRSG.

108 Pillar IV is headed by Joachim Rücker since February 2005. Council Joint Action (CFSP) 1999/522 was extended by Council Joint Action (CFSP) 1999/864 of 21 December 1999 [1999] OJ L 328/67 and Council Joint Action (CFSP) 2000/175 of 28 February 2000 [2000] OJ L 55/78; Council Regulation (EC) 1080/2000 on support for the United Nations Interim Mission in Kosovo (UNMIK) and the Office of the High Representative in Bosnia and Herzegovina (OHR) [2000] OJ L 122/27; Council Regulation (EC) 2098/2003 amending Regulation (EC) 1080/2000 on support for the United Nations Interim Mission in Kosovo (UNMIK) and the Office of the High Representative in Bosnia and Herzegovina (OHR) [2003] OJ L 316/1. 
structures and instruments that form the basis of a competitive, efficient market economy. ${ }^{109}$ That is not to say that "Europe's" influence is only felt within the framework of Pillar IV. EU Member States' presence also extends to the other three pillars, e.g. through their participation in the work which KFOR and OSCE carry out for UNMIK. ${ }^{110}$ In fact, since the end of the crisis, the EU and its Member States have devoted the lion's share of resources - military, financial, and human - to repair the damage of war and of decades of under-investment and neglect, to increase the capacity of local administration, and foster reforms: since 1999, the European Community has devoted over 1.6 billion to Kosovo, money which has been channelled via ECHO (in 2003, it was phased out of the province as the humanitarian crisis was over), ${ }^{111}$ the European Agency for Reconstruction (managing the bulk of CARDS funds), the funding of the operating costs of Pillar IV, ${ }^{112}$ and the financing of the Kosovo Consolidated budget via DG ECFIN's (the European Commission's Directorate General Economic and Financial Affairs) decision on exceptional financial assistance. ${ }^{113}$

Despite the fact that UNMIK (incl. the EU) gradually transferred a large number of competences to Kosovo's Provisional Institutions of SelfGovernment, and that many of the "Standards" were achieved, poverty and unemployment remained widespread. ${ }^{114}$ Bitterness and resentment

\footnotetext{
${ }^{109}$ Included among the achievements attributed by the EU to its work in Pillar IV are the creation of a modern market economy through the introduction of commercial and economic legislation conforming to European standards; the launch of the privatisation process stimulating economic development and investment; the successful switch to the Euro as the single currency; the creation of a working banking system with nine commercial banks including over 240 branches; the initiation of free trade agreements and integration of Kosovo into various regional and European economic structures; the transformation of the customs service into a modern organisation collecting over 70 per cent of the Kosovo Consolidated Budget funds; the introduction of various measures to counter economic crime and corruption; and the stabilisation of Kosovo's fragile power situation. See <http://www. euinkosovo.org/uk/about/about_pillar.php>.

110 For an overview of the experiences in EU-UN cooperation in Kosovo so far, see M Karnitschnig, 'The United Nations and the European Union in Kosovo: The Challenges of Joint Nation-building' in J Wouters, F Hoffmeister and T Ruys (eds), The United Nations and the European Union: An Ever Stronger Partnership (T.M.C. Asser Press, The Hague 2006) forthcoming.

111 See the thematic booklet published by the European Commission, ECHO in the Balkans - 12 Years of Humanitarian Action 1991-2003 (ECHO, Brussels 2003).

112 Unlike the first three pillars of UNMIK, the operational expenditure of Pillar IV is almost fully financed out of the European Commission's budget. See Council Regulation (EC) 2098/2003 amending Regulation (EC) 1080/2000 on support for UNMIK and OHR [2003] OJ L 316/1.

${ }^{113}$ Data available at the EU Pillar's website <http://www.euinkosovo.org/uk/about/about_ pillar.php>.

${ }^{114}$ In 2004, over half of Kosovo's 2 million people were living on or below the poverty line. The average daily income was 3 and the official unemployment rate 39.7 per cent. There
} 
grew over the "corrupt" and "colonial" ways of UNMIK's international staff. ${ }^{115}$ Local frustrations connected to the ambiguity over the final status spilled into organised inter-ethnic violence - as witnessed in March 2004. The status quo - i.e. "standards before status" - had become unsustainable and forced the international community to develop a fresh approach to promoting reforms and development in Kosovo. It was eventually acknowledged that working on the standards in the context of the future status was a better strategy than insisting on standards before status. Following the Comprehensive Review of the situation in Kosovo by UNSG Special Envoy Kai Eide in the summer of 2005, the UN Security Council on 24 October 2005 endorsed final status talks. ${ }^{116}$ This decision had been facilitated by the rapprochement between Priština and Belgrade after the resignation of Ramush Haradinaj as Kosovo's Prime Minister on 9 March 2005 and his surrender to the ICTY to face charges of persecuting Serbs, gypsies, and suspected collaborators among the ethnic Albanians.

\subsubsection{Final status talks}

On 10 November, the UN Security Council endorsed the Secretary General's intention to appoint Martti Ahtisaari, former President of Finland, as his Special Envoy to lead the political process, and established the following guiding principles for the process, as agreed to by the Contact Group:

(1.) The settlement of the Kosovo issue should be fully compatible with international standards of human rights, democracy and international law and contribute to regional security. (2.) The settlement of Kosovo's Status should conform with democratic values and European standards and contribute to realizing the European perspective of Kosovo, in particular, Kosovo's progress in the stabilization and association process, as well as the integration of the entire region in Euro-Atlantic institutions. (3.) The settlement should ensure multi-ethnicity that is sustainable in Kosovo. It should provide effective constitutional guarantees and appropriate mechanisms to ensure the implementation of human rights for all citizens in Kosovo and of the rights of members of all Kosovo communities, including the right of refugees and displaced persons to return to their homes in safety. (4.) The settlement should provide mechanisms to ensure

were daily debilitating power cuts. See Statistical Office of Kosovo, 'Series 1: Kosovo in Figures 2005', January 2006 <http://www.ks-gov.net/esk/index_english.htm>. See further B Knoll, 'From Benchmarking to Final status? Kosovo and the Problem of an International Administration's Open-ended Mandate' (2005) 16 EJIL,637-660.

115 See H Smith, 'Angry Kosovars call on "colonial” UN occupying force to leave' The Observer (19 October 2003) and Press release UNMIK/PR/1053, 4 November 2003.

116 See UN Doc S/PRST/2005/51. 
the participation of all Kosovo communities in government, both on the central and on the local level. Effective structures of local selfgovernment established through the decentralization process should facilitate the coexistence of different communities and ensure equitable and improved access to public services. (5.) The settlement of Kosovo's status should include specific safeguards for the protection of the cultural and religious heritage in Kosovo. This should include provisions specifying the status of the Serbian Orthodox Church's institutions and sites and other patrimony in Kosovo. (6.) The settlement of Kosovo's status should strengthen regional security and stability. Thus, it will ensure that Kosovo does not return to the preMarch 1999 situation. Any solution that is unilateral or results from the use of force would be unacceptable. There will be no changes in the current territory of Kosovo, i.e. no partition of Kosovo and no union of Kosovo with any country or part of any country. The territorial integrity and internal stability of regional neighbours will be fully respected. (7.) The Status settlement will ensure Kosovo's security. It will also ensure that Kosovo does not pose a military or security threat to its neighbours. Specific provisions on security arrangements will be included. (8.) The settlement of Kosovo's status should promote effective mechanisms to strengthen Kosovo's ability to enforce the rule of law, to fight organized crime and terrorism and safeguard the multi-ethnic character of the police and the judiciary. (9.) The settlement should ensure that Kosovo can develop in a sustainable way both economically and politically and that it can cooperate effectively with international organizations and international financial institutions. (10.) For some time Kosovo will continue to need an international civilian and military presence to exercise appropriate supervision of compliance of the provisions of the Status settlement, to ensure security and, in particular, protection for minorities as well as to monitor and support the authorities in the continued implementation of standards. ${ }^{117}$

It is within these parameters - no partition of Kosovo, no union with a neighbouring state and no return to pre-1999 conditions - that the UNSG Special Envoy will have to find a compromise agreement between Priština and Belgrade. On 7 November, the Council of the EU endorsed the appointment of Stefan Lehne as EU representative to support the UN Status Envoy in the implementation of his mandate. ${ }^{118}$ Ahtisaari started the final status talks on 21 November 2005 with a fact-finding mission to both capitals. What he found were two - at first sight - irreconcilable positions. The approximately 1.5 million ethnic Albanians in Kosovo en-

117 See UN Doc S/2005/709.

${ }^{118}$ See Council Conclusions Press Release 13622/05 (Presse 274) 7 November 2005. 
visage only one outcome: an independent Kosovo. Bajram Kosumi, then Prime Minister, was reported as having said: "A small country like Kosovo would feel insecure if it didn't have a UN seat." 119 For Belgrade, however, independence is anathema. The Serbs, who entered the final status negotiations with the puzzling slogan "more than autonomy, less than independence," are ready to concede de facto self-government as long as they retain sovereignty de jure. ${ }^{120}$ With the no-compromise Radical Party riding high in polls, Prime Minister Vojislav Koštunica ${ }^{121}$ has little negotiating space. Kosovo is still a taboo subject. It remains historic Serb territory which no politician can give away. Boris Tadić, the President of Serbia and Montenegro, was reported as having said: "For Serbia it's unacceptable to see Kosovo with a seat in the UN." ${ }^{122}$ Complicating the Kosovo question is the split-up with Montenegro. While Serbs believe they have not "lost" Montenegro in the sense that they face "losing" Kosovo to the ethnic Albanians, the break-away Montenegro has scarred the Serbian soul and reduced the room for compromise over Kosovo even more.

The Contact Group has so far avoided taking sides, but the US and the UK are increasingly leaning towards independence for Kosovo. ${ }^{123}$ France and other EU Member States are more cautious, concerned that early discussion of independence could take the pressure off Priština to negotiate and risk a Serb walk-out of the negotiations. ${ }^{124}$ The Contact Group agrees that minority rights must be guaranteed, peace-keeping troops must stay, and an international civilian mission - probably run by the European Union - be put in place. ${ }^{125}$ Russia and China, which had previously worried that an independent Kosovo would set a precedent for their claimed territories of Chechnya, Tibet, and Taiwan, were reported as having told the US Secretary of State Condoleezza Rice that they would not block the independence of Kosovo, because they consider the situation of Kosovo "unique." ${ }^{126}$ In the UN Security Council, Russia and China

119 See S Wagstyl, 'Why Kosovo might hold the key to the Balkans' future' Financial Times (19 February 2006).

${ }^{120}$ Under his formula, Kosovo would largely manage its own affairs - have its own executive, legislative, and judicial authorities - but remain nominally a part of Serbia and forgo diplomatic representation abroad - a single minister of foreign affairs, one minister of defence, and one single seat in the United Nations. The 100,000 Kosovo Serbs would have to benefit from a high level of minority rights protection.

${ }^{121}$ Koštunica became Prime Minister in spring 2004.

${ }^{122}$ See S Wagstyl, 'Why Kosovo might hold the key to the Balkans' future' Financial Times (19 February 2006).

${ }^{123}$ See 'Kosovo's future', SEEUROPE.NET, 15 February 2006.

124 Ibid.

${ }^{125}$ See chapter 2.3.4 below.

${ }^{126}$ See G Dinmore and D Dombey, 'Russia and China "pledge not to block new Kosovo"' Financial Times (14 March 2006). 
would probably abstain from voting on a proposed resolution that would grant independence to Kosovo.

Instead of tackling the status question head-on, Ahtisaari opted for a bottom-up approach. On 20-21 February 2006, the first round of direct negotiations between Serbs and Kosovar Albanians took place in Vienna. Middle-ranking officials met under the auspices of deputy UNSG Special Envoy Albert Rohan (Austria) to discuss rival schemes for the devolution of powers from Kosovo's central authorities to the municipalities. Effective provisions for the decentralisation of government will be crucial to the status settlement, as decentralisation can ensure that minority communities such as the Kosovo Serbs remain a vital part of Kosovo's future, and give impetus to the return of displaced persons who should be able to choose where they live in Kosovo. Although no agreement was reached on the issue, the negotiations were generally perceived to be largely constructive. After meeting government representatives in Belgrade, Ahtisaari announced that he would dispatch technical teams to Belgrade and Priština to pave the way for continuing negotiations on practical questions. In the first half of 2006, five more rounds of talks took place in Vienna. ${ }^{127} \mathrm{Al}-$ though the talks were inconclusive, they were described by Ahtisaari as constructive because they "clarified each side's stand." 128

While the final status process is expected to last for several months, the Contact Group, together with the EU High Representative, the EU Presidency, the European Commissioner for Enlargement, NATO's Secretary-General, the UN Special Status Envoy and the SRSG, expressed the belief that all possible efforts should be made to achieve a negotiated settlement in the course of 2006. ${ }^{129}$ The stakes are high. If the UN Special Envoy does not get Kosovo right, it could become perpetually underdeveloped and prone to unrest, or stay frozen in a decades-long stalemate like Cyprus. Equally important - and despite the fact that Kosovo is unusual because of the 1999 NATO military intervention that paved the way for this current process, the international community's handling of Kosovo will be read around the globe as having broader meaning for what it says about minority rights, self-determination, and the way to deal with breakaway territories.

\footnotetext{
${ }_{127}$ Prime Minister Bajram Kosumi, who stepped down over accusations by members of his coalition of being ineffective, was replaced by former KLA commander Agim Ceku, against whom Serbia has issued an arrest warrant. Despite protests from Belgrade, the EU supported the replacement. See Statement S074/06, 'Javier Solana, High Representative for the CFSP, welcomes confirmation of new Kosovo government' 10 March 2006.

${ }^{128}$ BETA News Agency, 12 June 2006.

129 Kosovo Contact Group Statement, London, 31 January 2006, <http://ue.eu.int/ueDocs/cms_Data/docs/pressdata/EN/declarations/88236.pdf>.
} 


\subsubsection{Main legal issues}

The question has been raised about what consequences the dissolution of the third Yugoslavia would have for the guarantee of its "sovereignty and territorial integrity" in Resolution 1244, all the more so as this Resolution referred to Kosovo as part of the FRY, not of Serbia. The Belgrade Agreement of 2002 includes an explicit precaution for a possible disintegration after three years: "If Montenegro withdraws from the state union, international documents related to the FRY, the UN Security Council Resolution 1244 in particular, shall relate to and fully apply on Serbia as its successor." 130 Thus, this weaving fault in Resolution 1244 was repaired. ${ }^{131}$ The suggestion that this provision violates the Resolution and re-introduces Serb sovereignty over Kosovo seems far-fetched. Resolution 1244 could not deny Kosovo being a province of the Serbian Republic under the Yugoslav constitution and, theoretically, Serbia might uphold the defunct "shell" of the FRY even after Montenegro's secession, if only because of Kosovo.

Whatever new status awaits Kosovo, it is vital that this arrangement does not trigger further rounds of irredentism and territorial claims; allowing Kosovo to merge with Albania would only destabilise Macedonia and other states in the region already wrestling with their own ethnic problems. Protecting minority rights is the surest means to head off insurrections before they begin.

\subsection{4. (Future) impact of EU intervention in Kosovo}

At first sight, the European Union's role in Kosovo since 1999 has been limited. "Embedded" in the international reconstruction effort, the EU acted under the responsibility of the United Nations. Yet, Europe's impact on the ground has been tangible, as the EU and its Member States devoted the lion's share of resources - military, financial, and human - to repair the damage of war and of decades of under-investment and neglect, to increase the capacity of local administration, and foster reforms. Unfortunately, paying the bills has not translated into greater visibility for the Union. But, this is about to change. The appointment by the UN Security Council of Martti Ahtisaari represents one of the first occasions since Lord Owen's rocky involvement in the early phases of the Bosnian war that a European has been given such pre-eminence in Balkans diplomacy. As noted before, the European Union fully participates in the status negotiations through its representative Stefan Lehne.

${ }^{130}$ Proceeding Points for a Restructuring of Relations between Serbia and Montenegro, reproduced in CEPS Europa South-East Monitor, Issue 31, January/February 2002.

${ }^{131}$ Strictly speaking, only the unlikely case of Serbia's secession would have unhinged Resolution 1244. 
However, his influence (and that of his boss, Javier Solana) is held back by a common stance of the Member States on (conditional) independence for Kosovo (UK vs. France).

One of the lessons learned from Bosnia is that, unless the chief negotiator has real powers, many in the Balkans will assume that this person is simply answering to his US deputy or more powerful handlers in the White House. It will only take a few times for Ahtisaari to step out of the room to get instructions before others around the table begin to think they should be negotiating directly with the front office. It is far from clear how the Bush administration, which does not seem to like being the junior partner in anything, will adjust to letting a European take the lead on Kosovo. Yet, Washington has enough on its hands right now (Iraq, Iran, Afghanistan) and should be happy that Europe has taken greater ownership of Balkan issues. There also continues to be an almost instinctive dislike within the White House for European leadership on matters of high diplomacy, and a fundamental distrust of Europe's ability to stick to tough positions. It will be Ahtisaari's challenge to keep the US close without creating the image of being Washington's lapdog. ${ }^{132}$

If the future for Kosovo is European, then "Europe" should not only wield real powers in the final status negotiations, but also in the implementation process. Fortunately, a bigger role for the EU in Kosovo looms on the horizon. If and when the final status negotiations lead to an agreement on how Belgrade and Priština could peacefully separate from each other, with internationally recognised borders, then UNMIK would in a final stage have to oversee the transfer of authority from Kosovo's PISG to institutions established under a political settlement (in line with Resolution 1244). The UN Security Council has made it clear in the guiding principles it adopted for this process that for some time "Kosovo will continue to need an international civilian and military presence to exercise appropriate supervision of compliance of the provisions of the Status settlement, to ensure security and, in particular, protection for minorities as well as to monitor and support the authorities in the continued implementation of standards." ${ }^{133}$ In October 2005, the SGSR initiated consultations with a view to preparing a technical assessment of the needs for the possible future international involvement in Kosovo, without prejudice to the outcome of the future status process. ${ }^{134}$ This assessment is being conducted by UNMIK together with the EU, OSCE, and NATO, as well as with the United Nations funds and agencies and bilat-

${ }^{132}$ See J Norris, ‘Kosovo: Get It Right, Now’ Le Monde Diplomatique (12 October 2005).

133 See UN Doc S/2005/709, 10 November 2005.

${ }_{134}$ Report of the Secretary-General on the United Nations Interim Administration Mission in Kosovo, UN Doc S/2006/45, 25 January 2006 press para 14. 
eral donors present in Kosovo. It focuses on four main areas: rule of law; good governance; democratisation, human rights and minority issues; and economic and fiscal issues.

It is believed that NATO, for some time to come, will continue to perform the hard-core security task and that the EU will restrict its future role in Kosovo to civilian crisis management. In December 2005, the General Affairs and External Relations Council of the EU discussed a joint report by the SG/HR and the Commission on the Union's future role and contribution in Kosovo. ${ }^{135}$ The report suggested that the EU should take over responsibility for the policing of Kosovo from UNMIK and train judges, prosecutors, and prison staff to guarantee the rule of law. The report also called for increased aid to Kosovo and talked of a tangible European prospect, whatever the outcome of the status talks. The Council asked the SG/HR and the Commission "to continue examination of these issues in coordination with other international actors, particularly in the areas of police and the rule of law (including contingency planning for a possible ESDP mission), economic development, and fostering Kosovo's European perspective, and to keep the relevant Council bodies actively engaged in order to ensure continuing timely preparation of an EU role in Kosovo." ${ }^{136}$ To this end, a Council/Commission joint mission was dispatched to Kosovo in February 2006 and a joint action was adopted by the Council on 10 April 2006 to send a planning team charged with designing an EU role in the fields of justice, police, and rule of law issues and the smooth transition of such selected tasks from UNMIK. ${ }^{137}$

At the time of writing, the political leaders of the Member States are not expected to gather enough courage to let "their" EU enter the highrisk territory of Kosovo by taking over the military operation from KFOR (assuming that the government of Kosovo would actually prefer EU involvement over that of the US within NATO). It seems that in 2006 the EU is still doubtful about its own military capabilities. This is a pity, as most of the approximately 17,000 KFOR troops are European anyway. ${ }^{138}$ Donald Rumsfeld, US Secretary of Defence, has indicated that he hopes

\footnotetext{
${ }^{135}$ See Council Conclusions Press release 14961/05 (Presse 318) 12 December 2005.

136 Ibid.

137 See Olli Rehn, 'The Western Balkans' (speech to the AFET Committee of the European Parliament, Brussels, 23 February 2006) SPEECH/06/125; and Council Joint Action (CFSP) 2006/304 of 10 April 2006 on the establishment of an EU Planning Team (EUPT Kosovo) regarding a possible EU crisis management operation in the field of the rule of law and possible other areas in Kosovo [2006] OJ L 112/19.

${ }^{138}$ Levels of the 36 troop-contributing nations are available at <http://www.nato.int/kfor >, KFOR's website. See also the monthly reports to the UN on the operations of KFOR, eg UN Doc S/2006/167, 15 March 2006, covering the period from 1 November to 31 December 2005.
} 
that US troop levels - currently at 1,700 - could be further reduced. ${ }^{139} \mathrm{~A}$ reorganisation of the EU's military involvement in $\mathrm{BiH}^{140}$ and invoking the necessary "Berlin Plus" arrangements would enable the European Union to seize a historic opportunity and finally stand up to the task of securing crisis situations on the continent without having to rely on US military might.

A final point concerns representation. In the event that the EU indeed launches a civilian ESDP mission in Kosovo, it will have to work side-by-side with NATO, UN agencies, and the international financial institutions. It would benefit the international community's goals and actions if it were to speak with a single voice. A (double-hatted) EU Special Representative could hold this high-profile post. Again, the lessons learned from Bosnia could help shape the position of a future high representative for Kosovo. ${ }^{141}$

\section{ESDP operations selon la lettre?}

\subsection{Bosnia-Herzegovina}

\subsubsection{EU Police Mission to Bosnia-Herzegovina}

On 1 January 2003 the EU launched its first-ever civilian crisis management operation within the framework of the ESDP: the EU Police Mission (EUPM) in Bosnia-Herzegovina. ${ }^{142}$ The EU thereby provided a follow-on mission to the United Nations International Police Task Force (IPTF). The aim of EUPM, the mandate of which was adjusted and extended for another two years, is to consolidate the achievements of the IPTF and the international community's work to establish sustainable policing

\footnotetext{
139 See D Sevastopulo and D Dombey, 'Rumsfeld wants to cut US presence in Kosovo' Financial Times (3 February 2006).

${ }^{140}$ As suggested by Günter Platter, the Austrian Minister of Defence, at the informal meeting of EU Defence Ministers on 6-7 March 2006 in Innsbruck. Platter was reported as having said that EUFOR Althea could be reduced with 700 troops in the second half of 2006 , and to 2,500 in the longer term. See 'EU-vredesmacht Bosnië verkleinen', NRC Handelsblad (7 March 2006). On EUFOR Althea, see below chapter 3.1.2.

${ }^{141}$ See G Niessen and J te Velde, 'In Kosovo is geen plaats voor het Bosnisch model' (2006) 60 Internationale Spectator 148-150; and M Karnitschnig, 'The United Nations and the European Union in Kosovo: The Challenges of Joint Nation-building' in J Wouters, F Hoffmeister and T Ruys (eds), The United Nations and the European Union: An Ever Stronger Partnership (T.M.C. Asser Press, The Hague 2006), forthcoming.

${ }^{142}$ As explained in section 1, the EU had already conducted civilian crisis management missions in cooperation with both the WEU and the UN. EUPM was the first operation for which the EU alone assumed leadership and responsibility. After having been invited thereto in the statement by the President of the Security Council UN Doc S/PRST/2002/33 (12 December 2002), the EU does, however, report to the Security Council on the activities of EUPM. For the most recent report, covering the period from 1 January to 31 December 2005, see UN Doc S/2006/125 (23 February 2006).
} 
arrangements under Bosnian ownership in accordance with best European and international standards. ${ }^{143}$ This overall goal is to be achieved in particular through monitoring, mentoring, and inspecting Bosnian police at the appropriate level, as well as through training and technical support. ${ }^{144}$ Understandably, EUPM does not have a mandate to enact legislation nor to enforce the law in Bosnia-Herzegovina. To possess either would be to undermine the principle of an independent, non-politicised police service that the international community is seeking to instil ten years after the war ended.

At the moment of writing, a total of 34 countries (the $25 \mathrm{EU}$ Member States and 9 third countries) contributed to a force of 207 police officers and support staff. ${ }^{145}$ In accordance with Article 25 TEU, the Political and Security Committee (PSC, most commonly referred to by its French acronym COPS) is tasked to exercise political control and strategic direction of the mission. The Head of Mission/Police Commissioner is in operational control of the mission, reporting to the SG/HR through the EU Special Representative in Bosnia. ${ }^{146}$ In order to support the domestic police forces in their work, EUPM initially co-located over 400 of its offic-

\footnotetext{
${ }^{143}$ See Council Joint Action (CFSP) 2002/210 on the European Union Police Mission of 11 March 2002 [2002] OJ L 70/1, which applied until 31 December 2005; and Council Joint Action (CFSP) 2005/824 on the European Union Police Mission (EUPM) in Bosnia and Herzegovina (BiH) of 24 November 2005 [2005] OJ L 307/55, applicable from 1 January 2006 to 31 December 2007.

${ }^{144}$ Ibid. The total cost of EUPM amounted to 38 million in 2003. See Council Decision (CFSP) 2002/968 concerning the implementation of Joint Action (CFSP) 2002/210 on the European Union Police Mission, of 10 December 2002 [2002] OJ L 335/1. Member States funded 18 million through staff secondment. The remaining 20 million in operational costs is financed through the Community budget. The latter figure dropped to 17.5 million per year in 2004 and 2005.

145 Bulgaria, Canada, Iceland, Norway, Romania, Russia, Switzerland, Turkey, and Ukraine have contributed police officers to EUPM. The EU has based itself on TEU art 24 to conclude agreements with these states on their (forces') participation in EUPM. For updates in contribution levels, see <http://www.eupm.org>.

${ }^{146}$ Sven Christian Frederiksen was appointed Head of Mission by Council Decision (CFSP) 2002/212 concerning the appointment of the Head of Mission/Police Commissioner of the European Union Police Mission (EUPM) of 11 March 2002 [2002] OJ L 70/8. Bartholomew Kevin Carty was appointed as his successor by Council Decision (CFSP) 2004/188 of 23 February 2004 [2004] OJ L 58/27. His mandate was extended until 31 December 2005 by Council Decision (CFSP) 2005/81 of 31 January 2005 [2005] OJ L 29/48. Carty was replaced by Vincenzo Coppola by PSC Decision EUPM/1/2005 ((CFSP) 2005/922) of 25 November 2005 [2005] OJ L 335/58. On 1 February 2006, Christian Schwarz-Schilling (Germany) succeeded Paddy Ashdown (UK) as High Representative and EUSR in BiH. See Council Joint Action (CFSP) 2006/49 appointing the European Union Special Representative in Bosnia and Herzegovina of 30 January 2006 [2006] OJ L 26/21. Lord Ashdown was appointed EUSR to BiH by Council Joint Action of 11 March 2002 on the appointment of the EU Special Representative in Bosnia and Herzegovina, [2002] OJ L $70 / 7$. This "double-hatting" greatly facilitated the coordination of the rule of law reform programmes between the UN and the EU.
} 
ers with $\mathrm{BiH}$ officers at medium and senior levels in all the police forces of $\mathrm{BiH}$, i.e. in the police forces of the two entities which make up $\mathrm{BiH}$, the Muslim-Croat Federation of Bosnia-Herzegovina (FBiH) and Republika Srpska (RS), and the independently administered Br ko District. ${ }^{147}$ It is the officers' joint task to implement EUPM's seven core programmes in crime policing, criminal justice, internal affairs, police administration, and public order. ${ }^{148}$ Each programme is implemented through a number of concrete projects, such as the Major and Organised Crime project and the Fight and Intervention against Human Trafficking project. In the field of internal affairs, one of EUPM's main tasks is to encourage the domestic authorities to deal with cases of non-compliance such as obstruction of EUPM, failure to adhere to the terms of the Dayton Agreement, or failure to uphold democratic policing principles. Only if the local authorities are seen to be failing in their duty to properly apply the disciplinary procedures will the matter be taken up by EUPM. In last instance, the EUPM Commissioner can recommend the removal of non-compliant officers to the HR/EUSR. ${ }^{149}$ Any officer so removed would be barred from any future service in the police. ${ }^{150}$

It is difficult to objectively assess how successful EUPM has been in the performance of its tasks since its inception. It is very much a question of whether one sees the bottle half-full or half-empty. At the 10th anniversary of Dayton, travelling outside the remarkably safe and pleasant environment of Sarajevo, one gets a sense that Bosnia is settling into a sort of normality. People expelled during the war are returning. The cost of life is relatively cheap. But while an end to war has brought a peace dividend, elections and freedom of expression, it also brought organised crime and hard drugs. On the basis of official press releases in the first year of operations, it seems that EUPM was "learning by doing". ${ }^{151}$ It

\footnotetext{
147 The present structure of the State of Bosnia and Herzegovina was established under the General Framework Agreement for Peace, initialled in Dayton on 21 November 1995 and signed in Paris on 14 December 1995, 35 ILM 1996, at 75.

148 On the activities of the EUPM in BiH, see the Agreement of 4 October 2002 between the EU and $\mathrm{BiH}$, annexed to Council Decision (CFSP) 2002/84 concerning the conclusion of the Agreement between the European Union and Bosnia and Herzegovina (BiH) on the activities of the European Union Police Mission (EUPM) in BiH of 30 September 2002 [2002] OJ L 293/1. In coordination with the HR/EUSR, international organisations in $\mathrm{BiH}$, as well as with senior $\mathrm{BiH}$ police authorities, EUPM's first Head of Mission, Police Commissioner Frederiksen, set two priorities for the mission, namely combating organised crime and guaranteeing the safe return of refugees and internally displaced persons, particularly those who return to an area where the ethnic group to which they belong is in the minority. EUPM's priorities developed over the course of the mission.

149 Para 6 of the Annex to Council Joint Action (CFSP) 2002/210.

${ }^{150}$ See C Mace, 'European Union Security and Defence Policy Comes of Age in the Balkans', (2003) EPC Working Papers <http://www.TheEPC.be>.

${ }^{151}$ See also A Nowak, L'Union en action: la mission de police en Bosnie (ISS,Paris 2003).
} 
increased border security after the assassination of Serbian Prime Minister Djindjić; it raided night clubs after reports of human trafficking; and it increased surveillance after indications of smuggling activity via the beaches at Neum (the $12 \mathrm{~km}$ long strip between Dubrovnik and Split which provides $\mathrm{BiH}$ with an entry to the Adriatic). Eight months down the road, EUPM acknowledged that the time had come to move beyond responding to violent incidents after they have occurred and to formulate a security doctrine which would enable it to prevent the eruption of renewed violence. A stable and secure environment in Bosnia, underpinned by a military presence, was - and still is - an essential element for the success of EUPM. At the outset, the EU was dependent on the military presence of NATO/SFOR to secure this environment, making close consultation between EUPM on the one hand, and the other international actors, in particular SFOR, on the other, imperative to establish the rule of law in Bosnia-Herzegovina. ${ }^{152}$ Procedures were simplified when, on 2 December 2004, the EU launched EUFOR Althea as a follow-on for SFOR. ${ }^{153}$ But this move did not translate into a qualitative or a quantitative improvement of EUPM's record. While EUPM was supposed to make local police more efficient crime fighters, the International Crisis Group found that statistics collected by the entity police forces indicated that crime had risen significantly since EUPM's mandate began. ${ }^{154}$ The most visible failure, however, was the inability of EUPM to conclude an agreement between the various local parties on police reform. ${ }^{155}$

Substantive police reform was long overdue in Bosnia-Herzegovina. During the 1992-1995 war, the police were a key instrument of ethnic cleansing - particularly in the RS and the Croatian areas of the FBiH. ${ }^{156}$

${ }_{152}$ To this end, Council Joint Action (CFSP) 2003/188 of 17 March 2003 amending Joint Action (CFSP) 2002/210 on the European Union Police Mission [2003] OJ L 73/9 was adopted to amend the original mandate of EUPM to give the SG/HR the authorisation to release classified information and documents up to the level "CONFIDENTIEL UE" to NATO/SFOR, to the host state, and to the third parties associated with the EU Joint Action, and up to the level "RESTREINT UE" to the Office of the High Representative, to the $\mathrm{UN}$, and to the OSCE.

153 See chapter 3.1.2 below.

${ }^{154}$ See ICG, 'Bosnia's Stalled Police Reform: No Progress, No EU' (6 September 2005) Europe Report,. John Erik Jensen, Chief of Quality Control of EUPM, was reported as having said that crime had risen approximately 40 per cent since EUPM began, but that the statistics used by local police agencies were extremely unreliable.

155 The EUPM can claim formation of the State Investigation and Protection Agency, a statelevel police agency, as a success, though one that must be shared with the OHR. The Council was proud to devote attention to this fact by publishing, in the first issue of its ESDP Newsletter, December 2005, a positive press report on the issue. See 'Wächter im Splitterstaat Süddeutsche Zeitung, (20 October 2005). For a more critical view, see M Merlingen and R Ostrauskaite, 'ESDP Police Missions: Meaning, Context and Operational Challenges' (2005) 10 EFA Rev 215-235.

156 See L Silber and A Little, The Death of Yugoslavia (Penguin Books 1996, London) rev ed. 
The war left Bosnia with three police forces: Bosniak, Croat, and Serb, each with its own jurisdictions. The first two merged fairly swiftly, at least nominally, but police throughout the whole country remained highly politicised, carrying out orders of policy-makers to obstruct implementation of the Dayton Peace Accords, in particular refugee return, and heavily involved in organised crime. The RS force was filled with war criminals and actively supported persons indicted by the ICTY. ${ }^{157}$ While EUPM was empowered to request the HR/EUSR to remove obstructionist police officers, this has proved such a cumbersome and protracted process that the EUPM has never exercised the power. ${ }^{158}$ For a long time, police reform (the structure of the police forces, their financing, and their relationship to the courts) remained hopelessly blocked due to obstruction from the Serbian side. The leading party in the RS - the Serbian Democratic Party (SDS) - openly blocked all efforts at reform and received active encouragement from the Serbian government in Belgrade, the Serbian Orthodox Church and Serbia's security structures, which desired to annex Republika Srpska as part of a Kosovo final status settlement. ${ }^{159}$ OHR, EUPM, and other international agencies in $\mathrm{BiH}$ proved incapable of convincing the Serbs to cooperate. A narrow interpretation of EUPM's rather weak mandate - to "monitor, mentor and inspect" - did not help to break the deadlock. It was not until heavy political pressure was applied on both Banja Luka and Belgrade, inter alia by making police reform a necessary precondition for $\mathrm{BiH}$ to open SAA negotiations with the $\mathrm{EU}$, that the Bosnian Serb parliament on 6 October 2005 backed down on blocking a key police law. ${ }^{160}$

Keen to score an early success for its nascent European Security and Defence Policy, the Union underestimated both the size and the complexity of the task in Bosnia-Herzegovina. EUPM took over poorly prepared, lacking inspiration, and expertise on how to devise a hard-hitting and non-negotiable strategy for "Europeanising" the police in $\mathrm{BiH}$. At the end of 2005, the Council reassessed the disappointing performance of EUPM and used the expiration of EUPM's mandate on 31 December 2005 to replace it with an institution charged, until 31 December 2007, with su-

\footnotetext{
157 Although the RS government's Srebrenica Report listed hundreds of individuals who took part in that massacre as still active duty officers, EUPM did not remove them or otherwise follow up. See ICG, 'Bosnia's Stalled Police Reform: No Progress, No EU' (6 September 2005) Europe Report. See, more generally, S Bose, Bosnia After Dayton: Nationalist Partition and International Intervention (Hurst \& Company, London 2002).

158 See ICG ‘Bosnia’s Stalled Police Reform: No Progress, No EU’ (6 September 2005) Europe Report.

${ }^{159}$ ICG 'Bosnia's Stalled Police Reform: No Progress, No EU' (6 September 2005) Europe Report.

160 See M Beunderman, 'Bosnia set to follow Croats and Serbs on EU track' (6 October 2005).EUObserver.com.
} 
pervising the implementation of police reform and restructuring, and the fight against organised crime. ${ }^{161}$ It seems unlikely that with this marginal widening of EUPM's mandate a robust police mission has been created that will remove recalcitrant police officials and earn respect in, as well as outside, Bosnia-Herzegovina.

\subsubsection{EUFOR Althea}

At the Copenhagen European Council in December 2002, the EU stated its willingness to follow on from a strong NATO-led military operation in Bosnia-Herzegovina by mid-2004. ${ }^{162}$ This ambition was re-stated by President Chirac and Prime Minister Blair at the Franco-British summit in Le Touquet in February 2003. SFOR, which operated under a robust Chapter VII mandate, ${ }^{163}$ was set up in Bosnia in December 1996 following the Dayton Accords that ended the civil war in the republic. It had a mandate to provide security and stability as well as to capture alleged war criminals and transfer them to the International Criminal Tribunal for the former Yugoslavia (ICTY) in The Hague. In June 2004, SFOR consisted of some 7,000 troops (reduced from 40,000 at the start, 33,000 in 1999, and from 16,000 in 2002 as part of a restructuring exercise), with European states contributing the majority of the force. ${ }^{164}$ Yet, leading an operation of this size would certainly represent a major task for the EU. The United States had initially given a cautious welcome to the Union's proposal, emphasising the need for a successful initial military operation in Macedonia before any takeover from SFOR could be considered. At the beginning of June 2003, however, the US put the brakes on the EU's plans to take over the large NATO-led mission, citing security reasons, the complexity of the mission, and continuing problems with the transfer of war criminals to the ICTY. ${ }^{165}$ High-level EU diplomats were not easily persuaded that, by postponing the take-over by the EU of NATO's mission, the US was in fact rendering the Union a favour and not bidding to thwart its efforts at giving its ESDP real visibility - which the EU's third military operation certainly would provide. ${ }^{166}$ Discontentment over the

\footnotetext{
${ }^{161}$ Art 2 of Council Joint Action (CFSP) 2005/824 on the European Union Police Mission (EUPM) in Bosnia and Herzegovina (BiH) of 24 November 2005 [2005] OJ L 307/55.

${ }^{162}$ EU Bull 12-2002, point I.9.29.

163 (1996) S/RES/1088.

${ }^{164}$ Data available at SFOR's website <http://www.nato.int/sfor >.

165 See <http://www.europeanvoice.com/current/article.asp?id=18147> and J Dempsey in N Gnesotto, EU Security and Defence Policy: The First Five Years (1999-2004) (EUISS, Paris 2004) 199.

${ }^{166}$ See J Dempsey, 'A Case of Overloaded Agendas' Financial Times (3 June 2003) in which the author points to the overloaded agenda from which the EU was suffering at the time: it was, inter alia, going through the most ambitious enlargement process in the history of
} 
spat between the US and a divided Europe over the latest war in Iraq certainly fuelled the Union's eagerness to prove its military capabilities by taking over some of the tasks performed by NATO and the UN, especially in the nearby Western Balkans. Yet, as most of the region increasingly shed its dependency on large international military forces (some 7,000 NATO-led troops in Bosnia, up to 20,000 in Kosovo, and a few hundred in Macedonia) and slowly moved to state- and institution-building, the need was growing to have professionally trained police forces capable of providing security. It was acknowledged that military missions could neither be open-ended nor carried out in isolation of building civilian structures. As such, the existing military mission in Bosnia-Herzegovina had to be part of a comprehensive approach in the country, and particularly geared towards providing the necessary security regime to allow for the deployment of civilian missions aimed at integrating police forces, improving training, and overhauling the judiciary and penal systems. ${ }^{167}$ In a decision hailed by the UN Security Council and member states of both organisations, NATO announced at its 28-29 June 2004 summit in Istanbul that SFOR would be replaced by an EU-led peacekeeping force by the end of $2004 .{ }^{168}$ The motives, however, had less to do with the real security situation in $\mathrm{BiH}$ than with EU eagerness to bolster its credibility as a security actor, and with the desire of the US to declare at least one of its long-term military deployments successfully over.

On the surface, EUFOR merely had to pick up where the NATO peacekeepers left off: patrolling the country; carrying out weapons collections; providing reassurance to local people. But the mission also faced two key challenges. The first was to deal with the issue of war criminals. While NATO managed to arrest 28 people indicted by the ICTY, it singularly failed to arrest the two people at the top of the most wanted list, the former Bosnian Serb leaders Radovan Karadzi and Ratko Mladi . Although NATO maintained a residual military presence comprising a small 200 -strong headquarters in Sarajevo (NHQSa) to advise the government of $\mathrm{BiH}$ on defence reform, counter-terrorism, and the capture of suspected war criminals, the spotlight was put on EUFOR: could it do better in catching the big fishes? Secondly, EUFOR would have to prove that it

European integration; it was involved in one of its most intense treaty amendment debates; it was working on its own "security doctrine"; and it was already carrying out two military operations: "Concordia" in Macedonia and "Artemis" in Bunia (DRC).

167 The 17-18 June 2004 European Council adopted such a comprehensive policy towards BiH. See EU Bull 6-2004, point I.12.51.

${ }^{168}$ See Istanbul Summit Communique issued by the Heads of State and Government participating in the meeting of the North Atlantic Council, NATO Press release (2004)096 28 June 2004; Summary of remarks by Javier Solana, EU High Representative for the CFSP, at the Istanbul NATO summit Istanbul 28 June 2004, S0179/04 and UNSC Res 1551 (9 July 2004). 
really could carry out a serious peacekeeping mission with thousands of troops on the ground. The question was whether the internal structures within the EU would allow for such a mission. If so, then EUFOR could boost the self-confidence of the EU in the field of EDSP and lead to the launching of similar missions in other trouble spots.

Authorised by UN Security Council Resolution 1575 (2004) for an initial planned period of twelve months, ${ }^{169}$ EUFOR Althea embarked on a mission to provide deterrence, ${ }^{170}$ continued compliance with the Dayton Accords, and to contribute to a safe and secure environment in BiH. ${ }^{171}$ The handover ceremony from NATO to EU peacekeepers took place at Camp Butmir, NATO's main base near Sarajevo, on 2 December 2004. ${ }^{172}$ With the adoption of Resolution 1575 (2004) under Chapter VII of the UN Charter, the Security Council authorised the Member States acting through EUFOR to take "all necessary measures" to effect the implementation of and to ensure compliance with Annexes 1-A and 2 of the Dayton Peace Accords, and stressed that the parties to those agreements would continue to be subject to such enforcement action by EUFOR (and NHQSa) as might be necessary to ensure the protection and the defence of EUFOR (and the NATO presence). The Resolution thus allowed for the use of force as applied by EUFOR troops in the gun battle that ensued after they stormed a house in Bosnia to apprehend Bosnian Serb war crimes suspect Dragomir Abazovi . ${ }^{173}$

169 (22 November 2004) S/RES/1575 In para 13, the UNSC expressed its intention to consider the terms of further authorisation as necessary in the light of developments in the implementation of the Dayton Peace Accords and the situation in $\mathrm{BiH}$. In para 18, the UNSC requested the Member States acting through or in cooperation with the EU (and NATO) to report to on the activities of EUFOR (and NHQSa), at least at three-monthly intervals.

170 That is, EUFOR would guarantee the peace by deterring anyone who might try to upset it.

${ }^{171}$ Council Decision (CFSP) 2004/803 on the launching of the European Union military operation in Bosnia and Herzegovina of 25 November 2004 [2004] OJ L 353/21, adopted on the basis of TEU art 17, provided the legal basis for the launching of EUFOR Althea. Art 3 states that, "[w]ithout prejudice to Article 17 of Joint Action (CFSP) 2004/570 this Decision shall remain in force until the Council decides to end the EU military operation in Bosnia and Herzegovina." For EUFOR Althea's mission statement, see art 1 of Council Joint Action (CFSP) 2004/570 on the European Union military operation in Bosnia and Herzegovina of 12 July 2004 [2004] OJ L 252/10.

${ }^{172}$ See Javier Solana, European Union High Representative for the Common Foreign and Security Policy, 'Launch of the EU "ALTHEA" operation in Bosnia and Herzegovina' Sarajevo (2 December 2004) S0337/04: "Today the EU assumes a new responsibility and commitment: here with the same spirit of generosity and efficiency as its predecessor from NATO. EUFOR will mesh with the EU's substantial engagement in so many areas: a formidable economic commitment, a Police mission deployed, a solid political relationship. All this is part of the journey to the only possible direction: the EU institutions."

${ }^{173}$ See T Küchler, 'EU troops kill wife of Bosnian war crimes suspect' (6 January 2006) EUObserver.com. 
In terms of operation and command, the PSC, under the responsibility of the Council, is tasked to exercise political control and strategic direction of the military operation. The Council authorised the PSC to take the relevant decisions in accordance with Article 25 TEU. ${ }^{174}$ This authorisation included the powers to take further decisions on the appointment of the EU Operation Commander and/or the EU Force Commander, to amend the planning documents, including the operation plan, the chain of command, and the rules of engagement. The powers of decision with respect to the objectives and termination of EUFOR, however, remained vested in the Council, assisted by the SG/HR. As part of the 1999 "Berlin Plus" arrangement, EUFOR draws on NATO assets and capabilities for Althea. ${ }^{175}$ The EU Operational Headquarters (EU OHQ) at Supreme Headquarters Allied Powers Europe (SHAPE) in Mons, Belgium, oversees EUFOR Althea. The EU OHQ draws on EU and NATO staff. The EU Command Element at NATO's Joint Forces Command, Naples in Italy and the EUFOR HQ at Camp Butmir in Sarajevo have control of the operation, reporting to EU OHQ. On 24 July 2004, Admiral Rainer Feist (Germany), NATO's Deputy Supreme Allied Commander for Europe (D-SACEUR), was appointed EU Operation Commander, ${ }^{176}$ but he was succeeded (in both posts) by General John Reith (UK) before he could even start working for EUFOR. ${ }^{177}$ The EU Military Committee (EUMC) monitors the proper execution of the EU military operation conducted under the responsibility of the EU Operation Commander. ${ }^{178}$ Major General David Leakey (UK) was appointed as the first EU Force Commander. ${ }^{179}$ On 5 December 2005, he was replaced by Major General Gian Marco Chiarini (Italy). ${ }^{180}$ The EU Force Commander maintains contact with the local authorities, in close coordination with the HR/EUSR, on issues relevant to his mission. ${ }^{181}$ Without prejudice to the chain of command, the EU Commanders coordinate closely with the HR/EUSR with a view to ensure consistency of the EU military operation with the broader context of the international community's activities in $\mathrm{BiH} .{ }^{182}$ At the moment of writing, a total of 33

${ }^{174}$ Art 6(1) of Council Joint Action (CFSP) 2004/570.

175 Art 1(3) of Council Joint Action (CFSP) 2004/570.

${ }^{176}$ Art 2 of Council Joint Action (CFSP) 2004/570.

177 PSC Decision BiH/2/2004 of 24 September 2004 on the appointment of an EU Operation Commander for the European Union military operation in Bosnia and Herzegovina (CFSP) 2004/733 [2004] OJ L 324/22.

178 Art 8(1) of Council Joint Action (CFSP) 2004/570.

179 Art 4 of Council Joint Action (CFSP) 2004/570.

180 PSC Decision BiH/6/2005 (CFSP) 2005/483 on the appointment of an EU Force Commander for the European Union Military Operation in Bosnia and Herzegovina of 14 June 2005 [2005] OJ L 173/14.

${ }^{181}$ Art 9 of Council Joint Action (CFSP) 2004/570.

182 Art 10 of Council Joint Action (CFSP) 2004/570. 
countries (22 EU Member States and 11 third countries) contributed to a force of 6,200 troops who operated under the renewed UN Chapter VII mandate of Security Council resolution 1639 (2005). ${ }^{183}$ In accordance with Article 28(3) TEU, the operational expenditure for EUFOR Althea is paid through contributions by Member States to a financial mechanism (ATHENA) based on GDP. ${ }^{184}$

It is now more than a year since EUFOR took over from SFOR in Bosnia-Herzegovina. The transition from SFOR to EUFOR was seamless and did not result in a security-gap. Thanks to its operational set-up and the symbiotic relationship with NATO and the rest of the "EU family" in Bosnia-Herzegovina, EUFOR has managed to establish its credibility and robustness from the outset. ${ }^{185}$ A good start was crucial for the consolidation of the European Union's ESDP, as EUFOR Althea is its most ambitious and significant operation within that framework. With more than 6,000 personnel, EUFOR Althea is not only the largest EU military mission to date, ${ }^{186}$ it is also part of a comprehensive endeavour to give Bosnia-Herzegovina a perspective for EU membership. ${ }^{187}$ The immediate goal

${ }^{183}$ See EU Council Secretariat, 'Factsheet on EU military operation in Bosnia and Herzegovina (Operation EUFOR - Althea)', (ATH/07 (update 7) December 2005). See PSC Decision $\mathrm{BiH} / 5 / 2004$ of 3 November 2004 amending Decision $\mathrm{BiH} / 1 / 2004$ on the acceptance of third states' contributions to the European Union military operation in Bosnia and Herzegovina and Decision $\mathrm{BiH} / 3 / 2004$ on the setting-up of the Committee of Contributors for the European Union military operation in Bosnia and Herzegovina (CFSP) 2004/822 [2004] OJ L 357/39. Albania, Argentina, Bulgaria, Canada, Chile, Morocco, New Zealand, Norway, Romania, Switzerland, and Turkey have contributed troops. The EU has based itself on TEU art 24 to conclude agreements on the participation of some of these third states' forces in EUFOR. See eg Council Decision (CFSP) 2005/593 concerning the conclusion of the Agreement between the European Union and the Republic of Chile on the participation of the Republic of Chile in the European Union military crisis management operation in Bosnia and Herzegovina (Operation ALTHEA) of 18 July 2005 [2005] OJ L 202/39. Denmark, Cyprus, and Malta have not contributed troops. In conformity with art 6 of the Protocol on the position of Denmark annexed to the Treaty of Amsterdam, C 340/101 [1997] OJ 1997, Denmark does not participate in the elaboration and implementation of decisions and actions of the EU which have defence implications. Therefore, Denmark does not participate in the implementation of Joint Action (CFSP) 2004/570, nor in the financing of the operation. Under the "Berlin Plus" arrangements, Cyprus and Malta are excluded from taking part in EU military operations using NATO assets and capabilities. See chapter 3.2.1 below. The neutral EU countries of Finland, Sweden, and Ireland have contributed troops to EUFOR Althea. Major troop contributions come from Germany (1,014), Italy (955), the UK (706) and France (402).

184 Art 12 of Council Joint Action (CFSP) 2004/570. On ATHENA, see Council Decision (CFSP) 2004/197 establishing a mechanism to administer the financing of the common costs of European Union operations having military or defence implications of 23 February 2004 [2004] OJ L 63/68.

185 See a happy J Solana, 'Foreword' (2 December 2005) EUFOR FORUM.

186 The two military operations which the EU carried out prior to launching EUFOR Althea, "Concordia" (FYROM) and "Artemis" (DRC), consisted of 400 and 1,400 troops respectively.

187 See Remarks of Javier Solana, EU High Representative for the CFSP, at the EUFOR Change of Command Ceremony, Sarajevo (6 December 2005) S402/05: "This comprehensive approach is what modern crisis management is all about." 
of Operation Althea was to contribute to maintaining a secure environment for the implementation of the Dayton Accords. In this respect, EUFOR Althea has proved to be a success. As part of its operations, EUFOR has conducted searches of companies suspected of pursuing activities in contravention of the Dayton Accords and it has conducted operations to disrupt illegal activities by those involved in organised crime. EUFOR has also supported de-mining operations and regularly carries out weapons collection activities across the country. Cooperating closely with EUPM, EUFOR put pressure on criminal networks. ${ }^{188}$ By doing so, it has also helped to disrupt support to ICTY indictees. ${ }^{189}$ In short, EUFOR's activities have helped to create the conditions under which Bosnia-Herzegovina was able to make progress in several important respects. For example, in September 2005, the RS and the $\mathrm{FBiH}$ agreed on a long debated military reform; a number of weeks later they agreed on the issue of police reform. This progress has been rewarded with the opening of negotiations on a Stabilisation and Association Agreement with the EU. However, as noted when discussing the role of EUPM, much progress is still to be made. However stable $\mathrm{BiH}$ is, potential for instability still exists: the country is awash with weapons; the three constituent peoples do not all share a common vision of the future and that is evident in daily politics which are driven by nationalistic agendas; and progress towards self-sustainability is significantly hindered by widespread organised crime and corruption which deeply intermingle with public life. The reform agenda, including the defence and police reforms, still needs to be implemented. In 2006, a new multi-ethnic professional army under a central general staff and one defence ministry at the federal level will be created. The new army will replace the military structures of the $\mathrm{BiH}$ entities. As the reform of the $\mathrm{BiH}$ Armed Forces and the build up of the $\mathrm{BiH}$ security sector continues, EUFOR (in cooperation with NHQSa) will have to stand ready to hand over more and more of its responsibilities to $\mathrm{BiH}$. The cooperation with ICTY must continue and be enhanced. Karadi and Mladi are still at large. Determining that the situation in the region continues to constitute a threat to international peace and security, the UN Security Council was

188 Asked what had been the main shortcomings of EUFOR in its first year of operations, Major General Leakey, Commander of the force, mentioned that in supporting the fight against organised crime, EUFOR very much had to learn by doing: "This new task has been demanding for everyone, from the soldiers on the ground to myself. Nevertheless, all EUFOR personnel have performed extremely well in this regard." Leakey also admitted that in running a multinational headquarters as efficiently as possible, one needs to overcome practical challenges such as language, different cultures and modus operandi. "But I believe that EUFOR has, again, risen to the challenge successfully." See 'Interview with Major General David Leakey, Commander of the stabilisation force (EUFOR)' 1 ESDP Newsletter (2005) 23.

189 Information available at EUFOR's website <http://www.euforbih.org>. See also N Hawton, 'Forces target Karadzic "network”, BBC News (15 March 2006). 
therefore right, by adopting Resolution 1639 (2005), to extend EUFOR's robust Chapter VII mandate for a further period of twelve months. ${ }^{190}$

\subsection{Macedonia}

\subsubsection{Operation Concordia}

As part of the larger commitment of the European Union to Macedonia, ${ }^{191}$ the Union deployed its inaugural military operation to contribute further to a stable and secure environment in the country. On 31 March 2003, the EU launched Operation Concordia to ensure the follow-up from NATO's operation "Allied Harmony". ${ }^{192}$ The European Union had hoped to take over from NATO in Macedonia as soon as the mandate of the Alliance's operation "Amber Fox" came to an end in December 2002. ${ }^{193}$ However, the EU-led operation could not go ahead until an agreement was reached with Turkey, within NATO, on EU access to NATO assets and capabilities (the so-called "Berlin Plus" arrangements). The negotiations between the EU and Turkey were deadlocked for months, until a breakthrough finally came on 12 December 2002, when the European Council of Copenhagen agreed that "Berlin Plus arrangements" and the implementation thereof would "only apply to those EU Member States which are also either NATO members or parties to NATO's 'Partnership for Peace', and which have consequently concluded bilateral security agreements with NATO". ${ }^{194}$ This formulation, which effectively excludes Cyprus (and Malta) from taking part in EU military operations using NATO assets, was sufficient to overcome Turkish objections and secure access to NATO assets. ${ }^{195}$ At the same summit, the European Council confirmed the Union's readiness to take over the military operation in Macedonia as soon as possible, in consultation with NATO. ${ }^{196}$ The European Council invited the relevant EU bodies to finalise work on the overall approach to the operation, including development of military options and relevant plans. The

190 (21 November 2005) S/RES/1639.

191 See chapter 2.1 above.

192 See Council Decision (CFSP) 2003/202 relating to the launch of the EU military operation in the Former Yugoslav Republic of Macedonia of 18 March 2003 [2003] OJ 76/43.

193 See EU Bull 6-2002, point I.7.14.

${ }^{194}$ EU Bull 12-2002, points I.9.27 and I.17.

195 The finalisation of the "Berlin Plus" arrangements was concluded with the signing of a Security of Information Agreement between the EU and NATO on 14 March 2003. See Council Decision (CFSP) 2003/211 concerning the conclusion of the Agreement between the European Union and the North Atlantic Treaty Organisation on the Security of Information of 24 February 2003 [2003] OJ L 80/35. The Agreement itself is not publicly accessible. For backgrounds and analysis, see M Reichard, (n 13).

196 EU Bull 12-2002, point I.9.28. 
Union's wish eventually became reality at the end of March 2003. A total of 27 countries (13 EU Member States ${ }^{197}$ and 14 non-EU countries ${ }^{198}$ ) contributed to a force of 350 soldiers plus 50 support staff. ${ }^{199}$

It is worth pointing out that the Irish government decided that it was unable to contribute personnel to Concordia due to the lack of explicit UN Security Council authorisation for the operation. ${ }^{200}$ Indeed, without referring to its legal basis in the UN Charter or determining the situation in Macedonia a threat to international peace and security, Security Council Resolution 1371 (2001), the single non-EU basis for the adoption of Joint Action 2003/92/CFSP on the establishment of Concordia, ${ }^{201}$ called for the full implementation of Resolution 1345 (2001) and further simply welcomed international efforts, including those of the OSCE, EU, and NATO, in cooperation with the Macedonian government, and other States, "to prevent the escalation of ethnic tensions in the area and to facilitate the full implementation of the Framework Agreement, thus contributing to peace and stability in the region." ${ }^{202}$ Resolution 1345 (2001) had done not much more than to call on states and appropriate international organisations to consider how they could best give practical help to efforts in the region to strengthen democratic, multiethnic societies and to assist the return of displaced persons (para. 11). ${ }^{203}$ The legal basis for the adoption of this resolution was also elusive, but like Resolution 1371 (2001) it recalled Resolution 1244 (1999) on Kosovo, which had determined that the

197 Denmark, for reasons already mentioned (n 183), did not participate in the elaboration, implementation, and financing of Council Joint Action (CFSP) 2003/92 on the European Union military operation in the Former Yugoslav Republic of Macedonia of 27 January 2003 [2003] OJ L 34/26. In accordance with TEU art 28(3), the operational expenditure arising from the Joint Action having military implications were charged to the Member States according to a formula based on GDP. Such costs totalled 6.2 million. The remaining costs were funded by participating states on a "costs lie where they fall" basis.

198 Bulgaria, Canada, Czech Republic, Estonia, Hungary, Iceland, Latvia, Lithuania, Norway, Poland, Romania, Slovakia, Slovenia, and Turkey.

199 The status of the EU-led forces in the FYROM was the subject of an agreement between the EU and the government of the Macedonia, concluded on the basis of TEU art. 24. See Council Decision (CFSP) 2003/222 concerning the conclusion of the Agreement between the European Union and the Former Yugoslav Republic of Macedonia on the status of the European Union-led Forces (EUF) in the Former Yugoslav Republic of Macedonia of 21 March 2003 [2003] OJ L 82/45, to which the so-called SOFA is annexed.

200 Nevertheless, Ireland did contribute to the mission's joint costs and played a full role in the Committee of Contributors. See PSC Decision FYROM/1/2003 on the setting-up of the Committee of Contributors for the European Union Military Operation in the Former Yugoslav Republic of Macedonia of 18 February 2003 [2003] OJ L 62/1.

${ }^{201}$ Council Joint Action (CFSP) 2003/92 preamble, recital 4.

202 (26 September 2001) S/RES/1371.

${ }^{203}$ (21 March 2001) S/RES/1345. The resolution also called on all states in the region to respect each other's territorial integrity and to cooperate on measures that foster stability and promote regional political, economic cooperation in accordance with the UN Charter, the basic principles of the OSCE, and the Stability Pact for South East Europe (para 12). 
situation "in the region" constituted a threat to international peace and security and gave NATO a Chapter VII mandate to deploy KFOR troops. While Ireland was probably right in insisting that Resolution 1244 (1999), adopted in the wake of NATO's armed intervention in Kosovo, could not serve as an appropriate legal basis for the deployment of an EU-peacekeeping mission in neighbouring Macedonia in 2003, it could hardly use this argument not to contribute troops to Operation Concordia. After all, the EU (supposedly) acted on the explicit request of the Macedonian government, not the other way around. ${ }^{204}$

As said at the beginning, the aim of Operation Concordia was to contribute further to a stable and secure environment to allow the Macedonian government to implement the 2001 Ohrid Framework Agreement so as to arrive at a situation where an international security presence was no longer needed. The command and control arrangements for Operation Concordia were drawn up in accordance with the "Berlin Plus" arrangements so as to create an EU chain of command which recognised the need for coordination with NATO. ${ }^{205}$ Admiral Rainer Feist, Deputy Supreme Allied Commander for Europe (D-SACEUR), ${ }^{206}$ was appointed the first EU Operation Commander. ${ }^{207}$ The Council appointed Brigadier-General Pierre Maral (France) as EU Force Commander. ${ }^{208}$ One of his tasks was to maintain contact with local authorities on issues relevant to his mission. Javier Solana and Alexis Brouhns (the EUSR in Macedonia at the time), each within their mandates, acted as primary points of contact with the Macedonian authorities for matters relating to the implementation of Joint Action 2003/92/CFSP. ${ }^{209}$

\footnotetext{
${ }^{204}$ The Macedonian President Trajkovski is supposed to have sent a formal invitation letter to the SG/HR on 17 January 2003. See Council Joint Action (CFSP) 2003/92 preamble, recital 5. But proof of the existence of this letter could not be found. On 13 March 2003, the SG/HR allegedly received a further letter from President Trajkovski, inviting the European Union to launch an operation in Macedonia. See Council Decision (CFSP) 2003/202 preamble, recital 1. Proof of the existence of this letter could also not be found.

205 Arts. 1-5, 7, 8, 10, and 11 of Council Joint Action (CFSP) 2003/92. It serves little purpose to repeat the arrangements here. They have been described in detail when discussing EUFOR Althea. See chapter 3.1.2 above. It should be emphasised, however, that the command and control arrangements for Althea were copied from those for Operation Concordia. See also C Mace, 'European Union Security and Defence Policy Comes of Age in the Balkans, (2003) EPC Working Papers <http://www.TheEPC.be>.

${ }^{206}$ See chapter 3.1.2 above.

207 Art 2 of Council Joint Action (CFSP) 2003/92.

${ }^{208}$ See Council Press release 6158/03 (Presse 38) 7 February 2003. Maral was replaced by Major General Luís Nelson Ferreira dos Santos (Portugal) as of 1 October 2003. On that date Concordia took over from France the responsibilities at the force s headquarters level. See art 2 of Council Decision (CFSP) 2003/563 on the extension of the European Union military operation in the Former Yugoslav Republic of Macedonia of 29 July 2003 [2003] OJ L 190/20.

209 Art 6 of Council Joint Action (CFSP) 2003/92.
} 
In terms of crisis management, the European Union has fared well in the case of Macedonia. Building on the successes of three NATO operations in the country (Essential Harvest, Amber Fox, and Allied Harmony), Operation Concordia provided continuity by carrying out classical peacekeeping tasks such as patrolling Macedonia's crisis areas, mostly near the Kosovo border. ${ }^{210}$ While it is true that, overall, the situation in Macedonia was relatively straightforward when compared to other Balkan conflicts, the security situation in the country remained nevertheless precarious. Incidents which took place at the beginning of 2003 and that apparently were the work of ethnic Albanian extremists unhappy with the Ohrid Framework Agreement had served as a reminder of the potential for a resurgence of ethnic violence Macedonia. ${ }^{211}$ Although Concordia was a relatively small force, its deployment was an important first test for both the Union's military crisis management capabilities and the "Berlin Plus" arrangements. On both accounts, the EU booked success. Concordia's deployment heralded a period of normalisation and stabilisation. Initially expected to last for a period of six months, ${ }^{212}$ the Council on 29 July 2003 agreed to extend Operation Concordia for one additional period until 15 December 2003, in line with the request made to the EU by the President of Macedonia. ${ }^{213}$ This shows the level of confidence which the Macedonian government had in the EU as a crisis-manager. Or perhaps it was the SG/HR who bought extra preparation time by convincing Trajkovski to wait until the end of the year before the EU's first-ever military mission would be transformed into a police mission. ${ }^{214}$

\subsubsection{EUPOL Proxima}

On 15 December 2003, a ceremony and a military parade in Skopje marked the official end of Operation Concordia. Immediately after-

\footnotetext{
${ }^{210}$ For an overview of Concordia's activities, see Concordia's website <http://www.delmkd. cec.eu.int/en/Concordia/main.htm>.

${ }^{211}$ See eg T Stojcevski, 'Abductions rattle Macedonians' (6 January 2003) IWPR Balkan Crisis Report No 395; T Stojcevski, 'Lions menace ends' (28 January 2003), IWPR Balkan Crisis Report No. 401; T Stojcevski, 'Militants threaten with renewed conflict' (3 February 2003) IWPR Balkan Crisis Report No 403,; and T Stojcevski, 'Extremists” target Macedonians' homes' (28 February 2003) IWPR Balkan Crisis Report No 410.

212 Art 3 of Council Decision (CFSP) 2003/202.

${ }^{213}$ Council Decision (CFSP) 2003/563 on the extension of the European Union military operation in the Former Yugoslav Republic of Macedonia of 29 July 2003 [2003] OJ L 190/20, refers to Trajkovski's letter of 4 July 2003, addressed to the SG/HR, whereby the President invited the EU to extend Operation Concordia until 15 December 2003 with the existing mandate and legal framework.

${ }^{214}$ Already ten weeks after the EU launched Operation Concordia, President Trajkovski suggested that the force be transformed into one that advises on border controls and the police. See E Jansson, 'Macedonia Seeks Greater Role for Balkans', Financial Times (9 June 2003).
} 
wards, the opening ceremony of the EU Police Mission in Macedonia (EUPOL Promixa) took place at the mission's new headquarters. Javier Solana spoke on both occasions. ${ }^{215}$ The SG/HR put the emphasis in both speeches on the continued engagement of the EU in Macedonia, a country which had moved from a situation were the main threat to stability was no longer armed conflict but criminality. Hence the need to shift the emphasis in the EU's support actions from the military to the police.

Upon the invitation of Prime Minister Branko Crvenkovski, ${ }^{216}$ the EU assumed responsibility for its second-ever police mission in the framework of the ESDP - its fourth ESDP mission of 2003. "Proxima" was launched for an initial period of 12 months. ${ }^{217}$ A planning team had been preparing its operations since 1 October 2003. ${ }^{218}$ As part of the wider Stabilisation and Association Process aimed at strengthening the rule of law in the region, Proxima aimed to support Macedonian efforts in moving closer towards the EU. In particular, Proxima's aim was to consolidate public confidence in policing by monitoring, mentoring, and advising the local police, and thus help to fight organised crime more effectively. "Proxima" would achieve this goal by a comprehensive reform of the Ministry of the Interior, including the creation of a border police and the development of an efficient and professional police service living up to European standards of policing - as required within the implementation of the Ohrid Framework Agreement. ${ }^{219}$ To this end, 35 states (the $15 \mathrm{EU}$ Member States, the 10 Acceding Countries, the 3 Candidate Countries at the time, and 7 third state ${ }^{220}$ ) contributed to a 200 man-strong police mission that was placed under the day-to-day supervision of Head of Mission/Police Commissioner Bart D'Hooge, who had also acted as the Police Head of Mission/Head of the Planning Team. ${ }^{221}$ He had to report to the

\footnotetext{
215 Javier Solana, 'EU High Representative for CFSP, attends ceremonies for termination of Operation Concordia and launch of Mission Proxima', (Skopje 15 December 2003) S0256/03.

${ }^{216}$ The invitation letter dated 16 September 2003.

217 Council Joint Action (CFSP) 2003/681 on the European Union Police Mission in the Former Yugoslav Republic of Macedonia (FYROM) of 29 September 2003 [2003] OJ L 249/66.

218 The planning team was foreseen by arts 1 and 2 of Council Joint Action (CFSP) $2003 / 681$.

219 Art 3 of Council Joint Action (CFSP) 2003/681.

${ }^{220}$ Canada, Iceland, Norway, Russia, Switzerland, Ukraine, and the US.

${ }^{221}$ Council Decision (CFSP) 2003/682 concerning the appointment of the Head of Mission/ Police Commissioner of the European Union Police Mission (EUPOL) in the Former Yugoslav Republic of Macedonia of 29 September 2003 [2003] OJ L 249/70. In accordance with art 13 of Council Joint Action (CFSP) 2003/681 the Council adopted - by written procedure and on the basis of TEU art 24 - a decision concerning the conclusion of the Agreement between the European Union and the Former Yugoslav Republic of Macedonia on the status and activities of the European Union Police Mission in the Former Yugoslav Republic of
} 
SG/HR through the EUSR. ${ }^{222}$ As with other ESDP operations, the PSC provided political control and strategic direction. Uniformed police personnel was seconded by the Member States. ${ }^{223}$ Officers were co-located at appropriate levels in Skopje, Tetovo, Kumanovo, Gostivar, and Ohrid. ${ }^{224}$

EUPOL Proxima was extended by one year in response to a request of the Macedonian Prime Minister Hari Kosotov on 1 October 2004. ${ }^{225}$ Brigadier General Jürgen Scholz was appointed as D'Hooge's replacement. ${ }^{226}$ Under the political guidance of the EUSR in Skopje, Ambassador Michael Sahlin, and in partnership with the local authorities, Proxima police experts continued to monitor, mentor, and advise the country's police, focusing on middle and senior management. It also further assisted in the creation of a border police service. In its second year of activities, EUPOL Proxima focused its activities on urgent operational needs within three programmes: "Public Peace and Order", "Organised Crime", and "Border Police". As a consequence, the mission expanded its geographical coverage to a country-wide deployment, while maintaining a higher presence in the former crisis area.

The European Union's second ESDP police-mission was successfully terminated on 9 December 2005. ${ }^{227}$ The closing of EUPOL Proxima preceded the decision of the 15-16 December European Council to award candidate country status to Macedonia as a reward for the "significant progress" it had made in the previous years towards meeting the political

Macedonia (EUPOL Proxima) [2004] OJ L 16/66. The Agreement included, where appropriate, the privileges, immunities, and further guarantees necessary for the completion and smooth functioning of the police mission. The Head of Mission had to sign a contract with the Commission. See art 5(2) of Council Joint Action (CFSP) 2003/681.

${ }^{222}$ The SG/HR gave guidance to the Head of Mission/Police Commissioner through the EUSR. Art 7 of Council Joint Action (CFSP) 2003/681.

${ }^{223}$ Each Member State had to bear the costs related to the police officers seconded by it, including salaries, medical coverage, allowances other than per diems, and travel expenses to and from Macedonia. See art 6(2) of Council Joint Action (CFSP) 2003/681 All police officers remained under full command of the appropriate national authority. National authorities transferred operational control to the Head of Mission (art 5(3)).

${ }^{224}$ For an overview of the operational challenges faced by Proxima, see M Merlingen and R Ostrauskaite, 'ESDP Police Missions: Meaning, Context and Operational Challenges' (2005) 10 EFA Rev. 213-235.

${ }^{225}$ Council Joint Action (CFSP) 2004/789 on the extension of the European Union Police Mission in the Former Yugoslav Republic of Macedonia (EUPOL PROXIMA) of 22 November 2004 [2004] OJ L 348/40.

${ }^{226}$ PSC Decision PROXIMA/2/2004 of 30 November 2004 concerning the appointment of the Head of Mission of the EU Police Mission in the former Yugoslav Republic of Macedonia, EUPOL Proxima (EC) 2004/846 [2004] OJ L 367/29.

${ }^{227}$ Statement by Javier Solana, EU High Representative for CFSP, on the occasion of the ceremony marking the end of the EU Police Mission in the former Yugoslav Republic of Macedonia, Skopje, (9 December 2005) S406/05. 
criteria for EU membership. ${ }^{228}$ Thus, the European Union's relationship with Macedonia was moved from post-crisis stabilisation to pre-accession integration.

\subsubsection{EUPAT}

The end of EUPOL Proxima did not signify the end of EU support to the broader rule-of-law area in Macedonia. With the establishment of the EU Police Advisory Team (EUPAT), the EU continued its efforts in supporting local authorities in police reform. ${ }^{229}$ EUPAT was launched on 15 December 2005 for a single period of six months. ${ }^{230}$

The main objective of EUPAT was to help the Macedonian government to modernise police structures, a priority reform area for further progress towards the EU. ${ }^{231}$ The team consisted of 30 experts seconded from EU Member States, ${ }^{232}$ who acted under the day-to-day leadership of Brigadier General Scholz, whose stay in Macedonia was thereby prolonged. ${ }^{233}$ Scholz, in turn, acted under the guidance of EUSR Erwan Fouéré and in partnership with the Macedonian authorities. ${ }^{234}$ Very much like the staff from its predecessor Proxima, EUPAT experts monitored and advised the Macedonian police (primarily middle and senior levels of management) in fields spanning border management, public order, and the fight against corruption and organised crime. EUPAT put emphasis on the implementation of police reforms, cooperation between the police and judiciary,

${ }^{228}$ EU Bull 12-2005, points I.12.23 and 24.

${ }^{229}$ During consultations with the EU, the Macedonian government had indicated that it would welcome, under certain conditions, a police mission to bridge the gap between the end of EUPOL Proxima and a planned project funded by CARDS aiming at providing technical assistance in the field.

${ }^{230}$ Council Joint Action (CFSP) 2005/826 on the establishment of an EU Police Advisory Team (EUPAT) in the Former Yugoslav Republic of Macedonia (fYROM) of 24 November 2005 [2005] OJ L 307/61.

${ }^{231}$ Art 1(2) of Council Joint Action (CFSP) 2005/826.

${ }^{232}$ Art 5(4) of Council Joint Action (CFSP) 2005/826. The staff comprised both EU police officers and civilian experts (including law enforcement monitors), assisted by 20 national staff. The headquarters for the Head of EUPAT and his staff were in Skopje, while EUPAT mobile units were co-located in Skopje, Tetovo, Ohrid, Bitola, and Stip, thereby covering all police regions. The necessary arrangements were made regarding the extension of the Agreement between the European Union and Macedonia on the status and activities of the EUPOL Proxima to EUPAT.

${ }^{233}$ PSC Decision EUPAT/1/2005 concerning the appointment of the Head of the EU Police Advisory Team Mission in the former Yugoslav Republic of Macedonia (fYROM), EUPAT of 7 December 2005 [2005] OJ L 346/46.

${ }^{234}$ Under the terms of Council Joint Action (CFSP) 2005/724 of 17 October 2005 [2005] OJ L 272/26, Fouéré was appointed EUSR. Fouéré was also appointed Head of the Commission's Delegation in Skopje. 
professional standardisation, and internal control. ${ }^{235}$ The EU set aside 1.5 million for this mission in Macedonia. ${ }^{236}$

When EUPAT's mandate ended on 14 June 2006, it handed over to a European Commission funded CARDS project that would continue to provide police advisors at central and local level. This evolution shows how far Macedonia has come in just five years. It also illustrates the EU's ability to adapt its different tools to specific situations, with specific needs. The European Union began by taking over a military operation from NATO, it continued with an ESDP police mission, and followed up with EUPAT and the European Commission projects.

\section{Concluding remarks}

The European Union has come a long way in the Western Balkans in just a few years. Where, in the 1990s, the EU stood by and watched the Balkans burn, it was the United States, within NATO, that had to put the fire out. In the aftermath of the Kosovo crisis, the Union finally found its voice to say no to violent conflict in the heart of Europe. In Macedonia, the European Union for the first time acted quickly and in a unified way to head off the plunge into inter-ethnic warfare. Thanks to the heavy involvement of its SG/HR Javier Solana, and with the support of NATO and OSCE, the EU brokered the Ohrid Framework Agreement (2001), which defined the roadmap towards a new inter-ethnic arrangement in Macedonia. The creation of the state union of Serbia and Montenegro marked a second important feat for the European Union and its SG/HR. The Belgrade Agreement has served its purpose to cool down tensions and lay down the criteria for an internationally acceptable separation of the two republics. In both cases, however, yesterday's diplomatic triumph could still become a Pyrrhic victory tomorrow due to the fragility of the arrangements and the volatility of political aspirations. The same goes for Kosovo, the final status of which is now under discussion. Here, the EU has a minimal role to play in the negotiating process, while it will probably carry all but the military responsibilities in the implementation phase. It seems that, for all the talk about the EU speaking with a single voice, political dissonances make it impossible for the SG/HR and his representative in the political process to play a bigger role. Similarly, the political leaders of the Member States consider the European military capacity too fragile still to back up words with force in the high-risk territory of Kosovo. In the last five years, the EU has taken its first careful steps in the field of the European Security and Defence Policy with the launching of its first-ever police and military missions. Macedonia and Bosnia-

${ }^{235}$ Art 2 of Council Joint Action (CFSP) 2005/826.

${ }^{236}$ Art. 8 of Council Joint Action (CFSP) 2005/826. 
Herzegovina have served as a good testing ground to make forthcoming ESDP missions a success. Lessons learned from these operations could be taken to heart when the EU decides to embark on its future missions, in Kosovo and further afield. In a way, it is a pity that the EU lacks the common will to take on the military challenge in Kosovo. A reorganisation of the EU's military involvement in Bosnia-Herzegovina and invoking the necessary "Berlin Plus" arrangements would enable the European Union to seize a historic opportunity and finally stand up to the task of securing crisis situations on the continent without having to rely on US military might. The Western Balkans may offer the European Union's one and only chance to develop credible and lasting foreign policy, security, and defence arrangements. 
